\title{
Influence of Nitrogen and Phosphorus on Microalgal Growth, Biomass, Lipid, and Fatty Acid Production: An Overview
}

\author{
Maizatul Azrina Yaakob ${ }^{1}$, Radin Maya Saphira Radin Mohamed ${ }^{2, *}$, Adel Al-Gheethi ${ }^{2}{ }^{\mathbb{D}}$, \\ Ravishankar Aswathnarayana Gokare ${ }^{3}$ (D) and Ranga Rao Ambati ${ }^{4, *}$ \\ 1 Institute for Integrated Engineering, Universiti Tun Hussein Onn Malaysia, Parit Raja, \\ Batu Pahat 86400, Johor, Malaysia; maizatulazrina@gmail.com \\ 2 Micropollutant Research Centre (MPRC), Faculty of Civil Engineering and Built Environment, Universiti Tun \\ Hussein Onn Malaysia, Parit Raja, Batu Pahat 86400, Johor, Malaysia; adelalghithi@gmail.com \\ 3 C. D. Sagar Centre for Life Sciences, Dayananda Sagar College of Engineering, Dayananda Sagar Institutions, \\ Kumaraswamy Layout, Bangalore 560078, Karnataka, India; rgokare@yahoo.co.in \\ 4 Department of Biotechnology, Vignan's Foundation of Science, Technology and Research \\ (Deemed to be University), Vadlamudi 522213, Guntur, Andhra Pradesh, India \\ * Correspondence: arangarao99@gmail.com (R.R.A); maya@uthm.edu.my (R.M.S.R.M)
}

check for updates

Citation: Yaakob, M.A.; Mohamed, R.M.S.R.; Al-Gheethi, A.;

Aswathnarayana Gokare, R.; Ambati,

R.R. Influence of Nitrogen and

Phosphorus on Microalgal Growth,

Biomass, Lipid, and Fatty Acid

Production: An Overview. Cells 2021,

10, 393. https://doi.org/10.3390/

cells10020393

Academic Editor: Alexei Solovchenko

Received: 26 December 2020

Accepted: 5 February 2021

Published: 14 February 2021

Publisher's Note: MDPI stays neutral with regard to jurisdictional claims in published maps and institutional affiliations.

Copyright: (c) 2021 by the authors. Licensee MDPI, Basel, Switzerland. This article is an open access article distributed under the terms and conditions of the Creative Commons Attribution (CC BY) license (https:/ / creativecommons.org/licenses/by/ $4.0 /)$.
Abstract: Microalgae can be used as a source of alternative food, animal feed, biofuel, fertilizer, cosmetics, nutraceuticals and for pharmaceutical purposes. The extraction of organic constituents from microalgae cultivated in the different nutrient compositions is influenced by microalgal growth rates, biomass yield and nutritional content in terms of lipid and fatty acid production. In this context, nutrient composition plays an important role in microalgae cultivation, and depletion and excessive sources of this nutrient might affect the quality of biomass. Investigation on the role of nitrogen and phosphorus, which are crucial for the growth of algae, has been addressed. However, there are challenges for enhancing nutrient utilization efficiently for large scale microalgae cultivation. Hence, this study aims to highlight the level of nitrogen and phosphorus required for microalgae cultivation and focuses on the benefits of nitrogen and phosphorus for increasing biomass productivity of microalgae for improved lipid and fatty acid quantities. Furthermore, the suitable extraction methods that can be used to utilize lipid and fatty acids from microalgae for biofuel have also been reviewed.

Keywords: microalgae; nitrogen; phosphorus; biomass; lipids; fatty acids

\section{Introduction}

The size of microalgae generally ranges between $1 \mu \mathrm{m}$ and $2 \mathrm{~mm}$. They can utilize light and carbon dioxide through the photosynthetic process to multiply and produce biomass [1,2]. Generally, microalgae are unicellular aquatic microorganisms that can be cultivated in a wide range of environmental conditions, either in saltwater, freshwater or wastewater, due to their high tolerance to environmental stress [3,4]. Different cultivation conditions of microalgae may affect microalgal growth rates, biomass yield and their nutritional content in terms of lipid and fatty acid production [3,5-8].

Microalgae are adopted to reduce pollution in waterways by a phycoremediation process to purify contaminants from water bodies and wastewater. Jais et al. [9] and Yaakob et al. [10] have reported microalgae-mediated reduction in pollutant levels in water bodies by the degradation of organic matters, uptake of heavy metals and regulation of chemical oxygen demand (COD) and biological oxygen demand (BOD) to the levels which are safe to be discharged. Scenedesmus sp. was adapted to treat swine wastewater wherein the total phosphorus (TP), total nitrogen (TN) and total carbon (TC) in swine wastewater were reduced up to $83 \%, 87 \%$ and $12 \%$, respectively, for 40 days through the phycoremediation process [11,12].

Microalgae generally comprise $28-70 \%$ of protein (on a dry matter basis), $10-20 \%$ of lipids and $10-50 \%$ of carbohydrates, respectively [13-15]. Studies by Hakalin et al. [16] and 
Baharuddin et al. [17] demonstrated that microalgae can be used in aquaculture for fish and shrimp feed due to their size, and are easily consumed. Microalgal feeds also promote rapid growth rates and high nutritional content in terms of lipids, proteins, carbohydrates, amino acids and fatty acids in the aquaculture-cultivated fish and shrimps.

Microalgae can be used to produce biofuel as an alternative energy source due to their high lipid content in the cells with an additional advantage of minimal land usage compared to terrestrial plants $[4,18]$. Few studies have demonstrated that microalgae can produce $58,700 \mathrm{~L} /$ ha of oil for biofuel, which is relatively higher compared to other crops such as jatropha and canola, with $1892 \mathrm{~L} / \mathrm{ha}$ and $1190 \mathrm{~L} / \mathrm{ha}$, respectively $[18,19]$. High lipid content in microalgal biomass is a prime factor of its suitability to produce biofuel. Zhang and Hong [20] reported that Scenedesmus sp. yielded 22\% lipids from their biomass. The main factors which may influence microalgae cultivation are nutrient content such as nitrogen and phosphorus, followed by mode of cultivation, temperature, light intensity, light:dark period, salinity, $\mathrm{pH}$, mixing, turbulence and also carbon dioxide concentration $[7,21]$. Nitrogen and phosphorus are essential macronutrients needed to promote algal growth and they regulate metabolic activities if supplied in an acceptable form. Various nitrogen and phosphorus concentrations in microalgae cultivation medium may influence lipid and fatty acid yield [4,18]. According to Munoz and Guieysse [22], microalgae can take up high nitrogen and phosphorus concentrations for the buildup of protein and nucleic acid synthesis in up to $40-60 \%$ of their dry weight.

This overview deals with the technical feasibility of utilization of nitrogen and phosphorus for microalgae growth, biomass production and their influence on nutritional composition, including lipid and fatty acids. The main aim of this review is to provide a summary of recent information concerning the role of nitrogen and phosphorus in microalgae cultivation that influences the growth of the organism, biomass yield, and productivity of lipid and fatty acids.

\section{Microalgae Nutrient Composition}

Several factors may influence microalgal growth, biomass, and lipid and fatty acids production. However, this review paper will focus only on how the limitation of nutrients (nitrogen and phosphorus) affects microalgal growth and its biochemical composition as studied in different microalgae species $[4-7,23]$.

\subsection{Role of Nitrogen}

Nitrogen is an essential macronutrient for microalgal growth and plays an important role in protein, lipid and carbohydrate synthesis [5,7]. Generally, nitrogen concentration significantly influences microalgal growth and their biochemical compositions; at the same time, depletion of nitrogen in cultivation medium causes a decrease in growth with concomitant increases in d lipid productivities [24]. Microalgae can assimilate nitrogen in the form of nitrate, nitrite, urea and ammonium [25]; nevertheless, nitrate is widely used for microalgae culture compared to ammonium salts as it is more stable with less likelihood of $\mathrm{pH}$ shift. Moreover, ammonia $\left(\mathrm{NH}_{4}{ }^{+}\right)$concentrations greater than $25 \mu \mathrm{M}$ are toxic for microalgae; thus, nitrate $\left(\mathrm{NO}_{3}{ }^{-}\right)$is used commonly in culture media [26]. However, the limitation of nitrogen in the culture medium may lower biomass production but would enhance lipid production. This was demonstrated by $\mathrm{Xu}$ et al. [25] who observed that a drop in $\mathrm{pH}$ in ammonium-supplemented cultivation medium of Ellipsoidion sp. caused a reduction in growth rate with simultaneous enhancement in eicosapentaenoic acid (EPA) and polyunsaturated fatty acids (PUFA) accumulation. Yang et al. [4] showed that biomass accumulation in Chlamydomonas reinhardtii was inhibited under nitrogen deficiency up to $31.7 \%$, with simultaneous increases in total fatty acid yield up to $93 \%$, coupled to enhancement in lipid production up to $113.46 \pm 1.78 \mathrm{mg} / \mathrm{L}$. Thus, it can be concluded that nitrogen concentration favors higher biomass productivity, and depletion of nitrogen shifts the flux to lipid production $[4,5,7,8]$. Table 1 shows microalgae cultivation in correlation with nitrogen content. 
Table 1. Microalgae cultivation correlation with nitrogen content.

\begin{tabular}{|c|c|c|c|}
\hline Microalgae Types & Experiment & $\begin{array}{l}\text { Outcomes Growth and Biochemical } \\
\text { Composition }\end{array}$ & Reference \\
\hline Nannochloropsis sp. & $\begin{array}{l}\text { Transferred from nitrogen-sufficient } \\
\text { to -deficient condition }\end{array}$ & Lipid content increased from $32 \%$ to $60 \%$ & [27] \\
\hline Chlorella vulgaris & $\begin{array}{l}\text { Lipid production under nitrogen } \\
\text { starvation conditions }\end{array}$ & Lipid productivity was 58.39 mg/L/day. & [28] \\
\hline Chlorella zofingiensis & $\begin{array}{l}10 \text { days cultivation in two } \\
\text { conditions: nitrogen starvation and } \\
\text { nitrogen repletion }(0 \mathrm{~g} / \mathrm{L} \text { and } \\
1.1 \mathrm{~g} / \mathrm{L} \text {, respectively })\end{array}$ & $\begin{array}{l}\text { Rapid growth in nitrogen-sufficient culture } \\
\text { medium, whereas growth inhibition under } \\
\text { nitrogen starvation condition }\end{array}$ & [3] \\
\hline Scenedesmus sp. & $\begin{array}{l}\text { Effects of nitrogen limitation and } \\
\text { starvation on morphological and } \\
\text { biochemical changes }\end{array}$ & $\begin{array}{l}\text { Nitrate starvation generates } 27 \% \\
\text { lipid accumulation }\end{array}$ & [29] \\
\hline Nannochloropsis oceanica & $\begin{array}{l}14 \text { days under nitrogen-deplete and } \\
\text { nitrogen-replete conditions }\end{array}$ & $\begin{array}{c}\text { Regulation of metabolic pathways along } \\
\text { with acetyl CoA synthesis and lipid } \\
\text { degradation for TAG synthesis }\end{array}$ & {$[30]$} \\
\hline $\begin{array}{l}\text { Chlorella sp. and } \\
\text { Nannochloropsis oculata }\end{array}$ & $\begin{array}{l}13 \text { days in Conway nutrient batch } \\
\text { cultures without nitrogen in the } 7 \text { th } \\
\text { day of growth }\end{array}$ & $\begin{array}{c}15.3 \pm 1.0 \% \text { lipid in Chlorella sp., } \\
33.7 \pm 2.8 \% \text { lipid in N. oculata under } \\
\text { nitrogen limitation }\end{array}$ & {$[31]$} \\
\hline $\begin{array}{l}\text { Phaeodactylum } \\
\text { tricornutum }\end{array}$ & $\begin{array}{l}\text { Lipid accumulation in } \\
\text { nitrogen-deficient medium }\end{array}$ & High lipid content $(53.04 \pm 3.26 \%)$ & [5] \\
\hline C. reinhardtii & $\begin{array}{l}\text { Effect of different nutrients on } \\
\text { standard TAP, TAP nitrogen } \\
\text { deficiency (T-N), TAP without } \\
\text { nitrogen and phosphorus (T-N-P), } \\
\text { TAP nitrogen deficiency with } \\
\text { additional phosphorus } 1 \mathrm{M}(\mathrm{K}) \mathrm{PO}_{4} \\
\text { (T-N+P) on growth and } \\
\text { lipid accumulation }\end{array}$ & $\begin{array}{l}\text { Lipid contents in cells increased as a result } \\
\text { of nitrogen-deficient conditions; the } \\
\text { highest lipid content was } 104.7 \% \text { in T-N-P } \\
\text { condition and the lowest lipid values were } \\
49.9 \% \text { in T-N condition }\end{array}$ & [32] \\
\hline I. galbana & $\begin{array}{l}\text { Effect of different nitrogen } \\
\text { concentrations }(0,36,72,144 \text { and } 288 \\
\text { mg/L) on the growth rate and } \\
\text { biochemical composition }\end{array}$ & $\begin{array}{l}\text { Growth decreased in nitrogen-deficient } \\
\text { conditions; in contrast, carbohydrates and } \\
\text { fatty acids showed the highest value, } 47 \% \\
\text { and } 75 \% \text {, respectively }\end{array}$ & [7] \\
\hline Scenedesmus obliquus & $\begin{array}{l}\text { Various nitrogen concentrations' } \\
\text { effect on growth and } \\
\text { lipid production }\end{array}$ & $\begin{array}{l}\text { Lipid production increased with increasing } \\
\text { nitrogen concentration; the highest cell } \\
\text { density }\left(1.7 \times 10^{7} \text { cells } / \mathrm{mL}\right) \text { and lipid } \\
\text { production }(242.4 \mathrm{mg} / \mathrm{L})\end{array}$ & {$[33]$} \\
\hline
\end{tabular}

Zhu et al. [3] reported that Chlorella zofingiensis showed rapid growth in nitrogensufficient culture medium, whereas growth inhibition under nitrogen starvation conditions was observed. Upon nitrogen starvation, lipid accumulation increased greatly in C. zonfingiensis cells, which is desirable for biodiesel generation. The results obtained by Zhu et al. [3] were similar to that of Zarrinmehr et al. [7] who reported that the cell cultures of Isochrysis galbana showed reduced growth in nitrogen-deficient conditions; and in contrast, carbohydrates and fatty acids levels enhanced by $47 \%$ and $75 \%$, respectively. Microalgae growth in nitrogen-deficient medium might change their lipid metabolic pathway and accumulate mainly triacylglycerides (TAGs), which are stored in the cytoplasm of microalgae as a source of carbon and energy $[4,28]$. Nitrogen-limiting conditions can decrease the thylakoid membrane cellular content, activates acyl hydrolase and stimulates phospholipid hydrolysis, resulting in increased intracellular content of fatty acyl-CoA [28]

Generally, nitrogen starvation is an effective technique to be used to increase lipid production in microalgae cells. Nitrogen-deficient culture conditions produced two-fold lipids compared to nitrogen-sufficient medium as reported by Jia et al. [30] and Pancha 
et al. [29]. However, nitrogen depletion conditions can lead to the reduction of microalgae biomass productivity [33]. I. galbana was cultivated in different nitrogen concentrations to induced stress for lipid production. The result reported that the lipid production in I. galbana decreased when nitrogen sources were below $288 \mathrm{mg} / \mathrm{L}$. According to Zarrinmehr et al. [7], the highest and lowest nitrogen concentration in culture medium triggered stress to microalgae cells. On the other hand, increased nitrogen concentration from $72 \mathrm{mg} / \mathrm{L}$ to $144 \mathrm{mg} / \mathrm{L}$ may enhance biomass production in I. galbana. This observation is similar to that of Feng et al. [34], who reported that C. zofingiensis was able to generate $65 \%$ lipids under nitrogen-deficient conditions. Table 2 summarizes the effect of nitrogen availability and starvation conditions on biomass yield, lipid content and fatty acids in algae.

Table 2. Effect of nitrogen availability and starvation conditions on biomass yield, lipid content and fatty acids in algae.

\begin{tabular}{|c|c|c|c|c|c|c|c|c|}
\hline $\begin{array}{l}\text { Microalgae } \\
\text { Strain }\end{array}$ & $\begin{array}{l}\text { Initial } \\
\text { Nitrogen } \\
\text { Available }\end{array}$ & $\begin{array}{c}\text { Final } \\
\text { Nitrogen } \\
\text { Starvation }\end{array}$ & $\begin{array}{l}\text { Cultivation of } \\
\text { Algae (Days) }\end{array}$ & Biomass Yield & $\begin{array}{l}\text { Lipid } \\
\text { Content }\end{array}$ & Fatty Acid & $\begin{array}{c}\text { Higher } \\
\text { Fatty Acids }\end{array}$ & Reference \\
\hline S. obliquus & $0 \mathrm{mM}$ & - & 14 & $719 \mathrm{mg} / \mathrm{L} / \mathrm{d}$ & $35 \%$ & $44.7 \pm 1.7 \%$ & C18:1 & [35] \\
\hline $\begin{array}{c}\text { C. } \\
\text { zofingiensis }\end{array}$ & $0 \mathrm{mg} / \mathrm{L}$ & - & 10 & $0.7 \mathrm{~g} / \mathrm{L}$ & $24.5 \%$ & $\begin{array}{c}12.10 \times 10^{-7} \mu \mathrm{g} \\
10.49 \times 10^{-7} \mu \mathrm{g} \\
6.25 \times 10^{-7} \mu \mathrm{g}\end{array}$ & $\begin{array}{l}\text { C16:0, } \\
\text { C18:1, } \\
\text { C18:2 }\end{array}$ & [3] \\
\hline $\begin{array}{l}\text { Scenedesmus } \\
\text { quadricauda }\end{array}$ & $0 \mathrm{mg} / \mathrm{L}$ & - & 30 & $265 \times 10^{4}$ cells $/ \mathrm{mL}$ & $226 \mathrm{mg} / \mathrm{L}$ & $\begin{array}{l}15.16 \% \\
25.08 \% \\
15.78 \%\end{array}$ & $\begin{array}{l}\text { C18:0, } \\
\text { C18:3 } \\
\text { C20:0 }\end{array}$ & [36] \\
\hline $\begin{array}{l}\text { Ankistrodesmus } \\
\quad \text { falcatus }\end{array}$ & $750 \mathrm{mg} / \mathrm{L}$ & - & 14 & $1740 \mathrm{mg} / \mathrm{L}$ & $59.6 \%$ & $\begin{array}{c}24.68 \pm 0.13 \% \\
19.2 \pm 0.66 \% \\
16.64 \pm 0.33 \% \\
11.77 \pm 0.73 \%\end{array}$ & $\begin{array}{l}\text { C16:0, } \\
\text { C18:1, } \\
\text { C18:2, } \\
\text { C18:3 }\end{array}$ & [37] \\
\hline $\begin{array}{l}\text { Phaeodactylum } \\
\text { tricornutum }\end{array}$ & $0 \mathrm{mg} / \mathrm{L}$ & - & 21 & $68.57 \pm 7.57 \mathrm{mg} / \mathrm{L}$ & $53.04 \pm 3.26 \%$ & $\begin{array}{c}17.73 \pm 8.40 \% \\
13.07 \pm 6.03 \% \\
1.81 \pm 1.25 \%\end{array}$ & $\begin{array}{l}\text { C16:0, } \\
\text { C16:1, } \\
\text { C20:5 }\end{array}$ & [5] \\
\hline $\begin{array}{l}\text { Entomoneis } \\
\text { paludosa }\end{array}$ & $83.56 \mu \mathrm{M}$ & $0.14 \mu \mathrm{M}$ & 35 & $2.00 \pm 0.11$ cells $/ \mathrm{mL}$ & $20.68 \pm 2.62 \%$ & $\begin{array}{l}36.7 \pm 6.9 \% \\
13.5 \pm 2.0 \% \\
20.1 \pm 3.2 \%\end{array}$ & $\begin{array}{l}\text { C16:0, } \\
\text { C18:0, } \\
\text { C18:1 }\end{array}$ & [38] \\
\hline $\begin{array}{l}\text { Rhodomonas } \\
\text { sp. }\end{array}$ & $1.5 \mathrm{~g} / \mathrm{L}$ & $113 \mathrm{mg} / \mathrm{L}$ & 8 & $2.5 \times 10^{6}$ cells $/ \mathrm{mL}$ & $30.3 \%$ & $\begin{array}{l}6.1 \%, \\
5.5 \%, \\
3.7 \%\end{array}$ & $\begin{array}{l}\text { C16:0, } \\
\text { C18:1, } \\
\text { C18:3 }\end{array}$ & [39] \\
\hline $\begin{array}{l}\text { Nannochloropsis } \\
\text { oceanica }\end{array}$ & $0 \mathrm{~g} / \mathrm{L}$ & NR & 3 & $20 \times 10^{6}$ cells $/ \mathrm{mL}$ & $58 \%$ & $\begin{array}{l}48 \% \\
40 \% \\
5 \%\end{array}$ & $\begin{array}{l}\text { C16:0, } \\
\text { C16:1, } \\
\text { C18:1 }\end{array}$ & [8] \\
\hline $\begin{array}{l}\text { Picocystis } \\
\text { salinarum }\end{array}$ & $9.375 \mathrm{mg} / \mathrm{L}$ & - & 20 & $0.7 \mathrm{~g} / \mathrm{L}$ & $33.87 \%$ & $\begin{array}{c}72.13 \mu \mathrm{g} / \mathrm{g}, \\
923.95 \mu \mathrm{g} / \mathrm{g}, \\
19.87 \mu \mathrm{g} / \mathrm{g}\end{array}$ & $\begin{array}{l}\text { C14:0, } \\
\text { C16:0, } \\
\text { C18:2 }\end{array}$ & [40] \\
\hline
\end{tabular}

Based on Table 2, it is clear that nitrogen plays an important role in influencing the fatty acids profile and the trends for fatty acids production for nitrogen starvation, and nitrogen availability conditions are quite similar with the highest yield of C14:0, C16:0 and C18:0 [3,5,8,35-40]. This statement was supported by Savvidou et al. [41], who reported that nitrogen limitation conditions will generate higher saturated fatty acids such as C14:0, C16:0 and C18:0. Delgado et al. [40] reported that at $9.375 \mathrm{mg} / \mathrm{L}$ nitrogen content, Picocystis salinarum produces $72.13 \mu \mathrm{g} / \mathrm{g}, 923.95 \mu \mathrm{g} / \mathrm{g}$ and $19.87 \mu \mathrm{g} / \mathrm{g}$ of C14:0, C16:0 and C18:2 fatty acids, respectively.

\subsection{Role of Phosphorus}

Phosphorus is another essential compound that plays a significant role in algal growth, lipid production, fatty acid yield and metabolic processes such as energy transfer, signal transduction and photosynthesis [6,42]. Phosphorous is an essential nutrient that makes up slightly less than $1 \%$ of total algal biomass and is required at approximately $0.03-0.06 \%$ in the medium to sustain algae growth $[26,42,43]$. Phosphorous is essential to microalgal cells for the production of cellular components such as phospholipids, DNA, RNA and ATP for the metabolic pathways that involve energy transfer and nucleic acid synthesis [44]. 
Microalgae can uptake phosphorus in the form of polyphosphate or orthophosphate to enhance their growth and nutritional content in the cells.

Polyphosphate in microalgae represents another form of cell protection from metal toxicity as it can bind with incoming metals into a detoxified complex [26]. C. reinhardtii accumulated copper $(\mathrm{Cu})$ and cadmium $(\mathrm{Cd})$ and survived the metals' toxic effects in polyphosphate-rich conditions [26]. However, some microalgae could accumulate more phosphorus in the form of orthophosphate $\left(\mathrm{PO}_{4}{ }^{3-}\right)$ and polyphosphate than required for growth as they can be converted to ATP under unfavorable nutritional conditions. The ATP is needed for pumping of the polyphosphate into the microalgae cell and for the conversion of phosphorus to polyphosphate. The source of energy for ATP is the photosynthetic process and also respiration $[2,28,45]$. Table 3 shows microalgae cultivation related to various phosphorus content in the medium.

Table 3. Microalgae cultivation in relation to phosphorus content.

\begin{tabular}{|c|c|c|c|}
\hline Microalgae Types & Experiment & Outcomes & Reference \\
\hline Eustigmatophyte sp. & Phosphorus limitation condition & $\begin{array}{c}\text { Triacylglycerols, TAG content increased } \\
\text { from } 12.9 \% \text { to } 15.1 \% \text { in absence of } \\
\text { phosphorus condition }\end{array}$ & [46] \\
\hline C. zofingiensis & $\begin{array}{l}\text { Affects phosphate on lipid } \\
\text { accumulation as a biodiesel feedstock }\end{array}$ & $\begin{array}{l}\text { Lipid content obtained from } \\
\text { phosphate-deficient was } 44.7 \% \text {, relatively } \\
\text { higher than cells grown in full } \\
\text { medium }(33.5 \%) \text {. }\end{array}$ & [34] \\
\hline C. vulgaris & $\begin{array}{l}\text { Biodiesel production under } \\
\text { phosphorus-sufficient conditions }\end{array}$ & $\begin{array}{c}\text { Lipid yield of C. vulgaris for biodiesel } \\
\text { production was } 58.39 \mathrm{mg} / \mathrm{L} / \text { day in } \\
\text { phosphate-sufficient conditions }\end{array}$ & [28] \\
\hline I. galbana & $\begin{array}{l}\text { Varied levels of phosphorus in } \mathrm{F} / 2 \\
\text { medium for biodiesel production }\end{array}$ & $\begin{array}{l}\text { Phosphorus starvation stimulated lipid } \\
\text { accumulation up to } 50 \% w / w\end{array}$ & [47] \\
\hline Scenedesmus sp. & $\begin{array}{l}\text { Phosphorus-rich medium from public } \\
\text { market wastewater treated for } 8 \text { days }\end{array}$ & $\begin{array}{l}\text { Total phosphorus in medium reduced } \\
\text { about } 82.17 \%\end{array}$ & [48] \\
\hline $\begin{array}{l}\text { Chlorella ellipsoidea and } \\
\text { Chlorococcum infusionum }\end{array}$ & $\begin{array}{l}\text { Phosphorous starvation culture } \\
\text { for } 30 \text { days }\end{array}$ & $\begin{array}{c}\text { Total lipid content of Chlorella } \\
(41.8 \pm 1.9 \% \text { at } 16 \text { days of incubation } \\
\text { period) and Chlorococcum ( } 31.3 \pm 1.0 \% \text { at } \\
18 \text { days of incubation period) }\end{array}$ & [49] \\
\hline Scenedesmus obtusiusculus & $\begin{array}{l}\text { Cultivated in BG-11 medium under } \\
\text { non-limiting conditions }\end{array}$ & $\begin{array}{c}6.4 \% w / w \text { lipid yield after } \mathrm{SCCO}_{2} \\
\text { extraction }\end{array}$ & {$[50]$} \\
\hline Scenedesmus sp. & $\begin{array}{c}\text { Resuspension in modified SE medium } \\
\text { with } 2 \mathrm{mg} / \mathrm{L} \mathrm{NaH}_{2} \mathrm{PO}_{4} \cdot{ }_{2} \mathrm{H}_{2} \mathrm{O} \\
\text { for } 9 \text { days }\end{array}$ & $\begin{array}{c}\text { The highest lipid production }(350 \mathrm{mg} / \mathrm{L}) \\
\text { and lipid content }(41.0 \%) \text { were obtained } \\
\text { by addition of } 2 \mathrm{mg} / \mathrm{L} \mathrm{NaH} \mathrm{PO}_{4} \cdot{ }_{2} \mathrm{H}_{2} \mathrm{O} \\
\text { every } 2 \text { days }\end{array}$ & [6] \\
\hline Chlorella sp. & $\begin{array}{l}\text { Lipid enhancement through nutrient } \\
\text { starvation }\end{array}$ & $\begin{array}{c}\text { Under phosphate starvation, the lipid } \\
\text { content was } 13.9 \% \text {. }\end{array}$ & [51] \\
\hline
\end{tabular}

Mulbry et al. [52] showed that microalgae have high efficiency to absorb inorganic phosphate from wastewater by luxurious uptake in the range of $70 \%$ to $90 \%$ compared to optimal levels needed for their growth [53]. It is also reported that microalgae growth and phosphate uptake are linearly proportional to the biomass yield. Chu et al. [28] demonstrated that Chlorella vulgaris had been cultivated for biodiesel production under phosphorus-sufficient conditions. The result showed that the lipid yield of $C$. vulgaris for biodiesel production was $58.39 \mathrm{mg} / \mathrm{L} /$ day in phosphate-sufficient conditions, which was relatively higher than in a phosphate-deficient regime. Thus, it can be concluded that phosphate is an important macronutrient for microalgal lipid production [28]. However, the phosphorus uptake by microalgae can reach saturation due to the limitation of light, and reduction of carbon dioxide and oxygen levels in the culture medium. 
Phosphorus is an essential nutrient for microalgae growth and cell division, and its requirement is varied in different microalgae species. According to Roopnarain et al. [47] the optimum phosphorus concentration for microalgae is in the range of $0.001 \mathrm{~g} / \mathrm{L}$ to $0.179 \mathrm{~g} / \mathrm{L}$. Phosphorus limitation is an efficient environmental pressure to induce lipid accumulation $[6,18]$. The lipid content in Scenedesmus sp. has increased under reduced phosphorus levels in the medium. The Scenedesmus sp. grown in $50 \mathrm{mg} / \mathrm{L}$ phosphorus achieved $22.3 \%$ lipid content, whereas lipid yield reached $42.5 \%$ in $1 \mathrm{mg} / \mathrm{L}$ phosphorus [6]. Similarly, Rhodosporidium kratochvilovae under limited phosphorus concentration $(0.05 \mathrm{~g} / \mathrm{L})$ produced $51.7 \pm 0.81 \%$ lipid content after eight days of cultivation [32]. Under the limitation of phosphorus, R. kratochvilovae formed big irregular-sized lipid droplets (LD) and enhanced TAG accumulation, which improves the biodiesel production properties like oxidative stability, viscosity, cetane number and cold filter plugging point [32].

Phosphorus-limited conditions in I. galbana showed that the phosphorus starvation medium ( $0 \%$ ) and limited P medium (12.5\%) induced high lipid content up to $50 \%(w / w)$ on 14 days of cultivation [47]. Besides that, the study also reveals that under stress conditions, I. galbana tends to use all available phosphorus in their cell for survival. Limited phosphorus concentrations could support continuous cell growth as well as enhance lipid accumulation in microalgae by switching photosynthetic carbon partitioning toward energy-rich storage macromolecules, mainly lipids, under stress conditions. Carbon partitioning blocks $\mathrm{CO}_{2}$ and starch synthesis, driving the metabolism towards lipid production for energy storage in phosphorus stress conditions $[6,18]$. The observation was corroborated by Feng et al. [34], who showed that phosphorus-limited conditions were suitable for lipid generation in C. zofingiensis. Table 4 summarizes the effect of nitrogen availability and starvation conditions on biomass yield, lipid content and fatty acids in algae.

Table 4. Effect of phosphorus availability and starvation conditions on biomass yield, lipid content and fatty acids in algae.

\begin{tabular}{|c|c|c|c|c|c|c|c|c|}
\hline $\begin{array}{l}\text { Microalgae } \\
\text { Strain }\end{array}$ & $\begin{array}{c}\text { Initial } \\
\text { Phosphorus } \\
\text { Available }\end{array}$ & $\begin{array}{c}\text { Final } \\
\text { Phosphorus } \\
\text { Starvation }\end{array}$ & $\begin{array}{l}\text { Cultivation } \\
\text { of Algae } \\
\text { (Days) }\end{array}$ & Biomass Yield & $\begin{array}{l}\text { Lipid } \\
\text { Content }\end{array}$ & Fatty Acid & $\begin{array}{l}\text { Higher Fatty } \\
\text { Acids }\end{array}$ & Ref \\
\hline Phormidium sp. & $0.02 \mathrm{~g} / \mathrm{L}$ & - & 15 & $0.130 \mathrm{~g}$ & $27.9 \%$ & $\begin{array}{l}34.667 \% \\
11.266 \% \\
27.912 \%\end{array}$ & $\begin{array}{l}\text { C16:0, } \\
\text { C18:0 } \\
\text { C20:2, }\end{array}$ & [54] \\
\hline Chlorella sp. & $32 \mu \mathrm{M}$ & - & 22 & $2 \mathrm{~g} / \mathrm{L}$ & $23.60 \%$ & $\begin{array}{l}35.48 \%, \\
33.90 \%\end{array}$ & $\begin{array}{l}\text { C16:0, } \\
\text { C18:0 }\end{array}$ & [55] \\
\hline $\begin{array}{l}\text { C. ellipsoidea, } \\
\text { C. infusionum }\end{array}$ & $1.5 \mathrm{~g} / \mathrm{L}$ & - & 30 & $\begin{array}{l}1.56 \pm 0.06 \mathrm{~g} / \mathrm{L} \\
2.17 \pm 0.12 \mathrm{~g} / \mathrm{L}\end{array}$ & $\begin{array}{l}41.8 \pm 1.9 \% \\
31.3 \pm 1.0 \%\end{array}$ & $\begin{array}{l}21.62 \pm 0.94 \% \\
30.32 \pm 2.68 \%\end{array}$ & C18:1, & [49] \\
\hline $\begin{array}{l}\text { Rhodosporidium } \\
\text { kratochvilovae }\end{array}$ & $0.05 \mathrm{~g} / \mathrm{L}$ & - & 10 & $12.65 \pm 0.12 \mathrm{~g} / \mathrm{L}$ & $51.7 \pm 0.81 \%$ & $\begin{array}{l}10.36 \pm 0.59 \% \\
66.79 \pm 0.21 \% \\
10.48 \pm 0.43 \%\end{array}$ & $\begin{array}{l}\text { C18:0, } \\
\text { C18:1, } \\
\text { C18:2 }\end{array}$ & [32] \\
\hline C. reinhardtii & $0 \mu \mathrm{g} / \mathrm{mg}$ & - & 7 & $1.1 \mathrm{~g} / \mathrm{L}$ & $105.00 \mu \mathrm{g} / \mathrm{mg}$ & $\begin{array}{l}35.86 \pm 0.25 \mu \mathrm{g} / \mathrm{mg} \\
22.12 \pm 0.12 \mu \mathrm{g} / \mathrm{mg} \\
22.84 \pm 0.08 \mu \mathrm{g} / \mathrm{mg}\end{array}$ & $\begin{array}{l}\text { C16:0, } \\
\text { C18:2, } \\
\text { C18:3 }\end{array}$ & [4] \\
\hline $\begin{array}{l}\text { Scenedesmus } \\
\text { sp. }\end{array}$ & $2 \mathrm{mg} / \mathrm{L}$ & - & 9 & $0.6 \mathrm{~g} / \mathrm{L}$ & $41.0 \%$ & NR & $\begin{array}{l}\text { C16:0, } \\
\text { C18:1 }\end{array}$ & [6] \\
\hline C. reinhardtii & $0.4 \mathrm{mg} / \mathrm{L}$ & - & 14 & $0.08 \mathrm{mg} / \mathrm{L}$ & NR & $\begin{array}{c}56 \% \\
28.8 \%\end{array}$ & $\begin{array}{l}\text { C16:0, } \\
\text { C18:3 }\end{array}$ & [56] \\
\hline $\begin{array}{l}\text { Nannochloropsis } \\
\text { oceanica }\end{array}$ & $0 \mathrm{~g} / \mathrm{L}$ & - & 6 & $2.5 \mathrm{mg} / \mathrm{L}$ & $337 \mathrm{mg} / \mathrm{g}$ & $\begin{array}{l}37.3 \pm 0.1 \% \\
30.8 \pm 0.3 \% \\
10.7 \pm 0.8 \%\end{array}$ & $\begin{array}{l}\text { C16:0, } \\
\text { C16:1, } \\
\text { C20:5 }\end{array}$ & [57] \\
\hline N. oceanica & $0 \mathrm{~g} / \mathrm{L}$ & - & 14 & $0.29 \mathrm{~g} / \mathrm{L}$ & $23.7 \%$ & $\begin{array}{l}13.93 \%, \\
26.31 \%\end{array}$ & $\begin{array}{l}\text { C18:1, } \\
\text { C16:1. }\end{array}$ & [41] \\
\hline
\end{tabular}

It is evident from Table 4 that the fatty acids profile in microalgae cultivated in phosphorusreplete and -deplete conditions are predominantly of C16:1 and C18:1 [4,6,32,41,49,54-57]. 


\section{Microalgae Cultivation Medium}

Microalgae commercialization is limited due to high operational costs such as labor, materials and chemicals, facilities, energy, low biomass yields and also the contamination risks [58,59]. Therefore, it is necessary to have a cultivation system that is efficient to reduce production costs by enhancing biomass productivity. Conventionally, microalgae were cultivated in open ponds and also tubes for biomass production [60,61]. However, this conventional cultivation technique has several drawbacks such as the risk of contamination by bacteria and protozoa and costs of electricity and water [62]. To encounter some of these drawbacks, the algae biomass production may be undertaken using wastewater medium [63], coupled to low energy-intensive harvesting methods and also effective extraction procedures [64].

Microalgae cultivation in large scales consume less land compared to the other crops, and the biofuels obtained from microalgae biomass are known as carbon neutral fuels as they use atmospheric carbon during photosynthesis [65]. Singh et al. [37] demonstrated that the lipid productivity of Ankistrodesmus falcatus had been influenced by nutrient-rich cultivation medium consisting of nitrogen and iron such as nitrogen $750 \mathrm{mg} / \mathrm{L}$ and iron (Fe) $9 \mathrm{mg} / \mathrm{L}$, wherein fatty acid production was $59.6 \%, 74.07 \mathrm{mg} / \mathrm{L} / \mathrm{d}$ and $38.49 \%$, for N, P and Fe, respectively. Similarly, Ji et al. [66] studied the effect of the starvation of nitrogen, phosphorus and sulfur in the cultivation medium on growth and lipid production in Tetrasemis subcordiformis. The results revealed that the cell growth in T. subcordiformis slowly increased during nutrient deprivation, indicating that the nutrients reservoir inside its cells facilitates sustenance of growth until the availability of the essential nutrients [66]. Interestingly, higher nitrogen $(\mathrm{N})$ to phosphorus $(\mathrm{P})$ ratio in the culture medium caused phosphorus deprivation for microalgae growth [65].

\subsection{Growth Rates}

The composition of nitrogen and phosphorus relatively affect microalgae growth $[18,26,67]$. According to Zhu, [3] growth of C. zofingiensis was severely inhibited upon nitrogen depletion and the results were similar to a study carried out by Ji et al. [66] in Tetrasemis subcordiformis. Besides that, low growth rates in nitrogen-deficient conditions in microalgae tend to accumulate higher saturated fatty acids (SFA) and monounsaturated fatty acids (MUFA) into neutral lipids. Whereas, higher growth results in a high accumulation of polyunsaturated fatty acids (PUFA) [68].

Here we discuss the measurement of growth of algae for determining the biomass productivities. Firstly, the growth of microalgae can be determined by cell number counting using a hemocytometer after appropriate dilution (Figure 1).

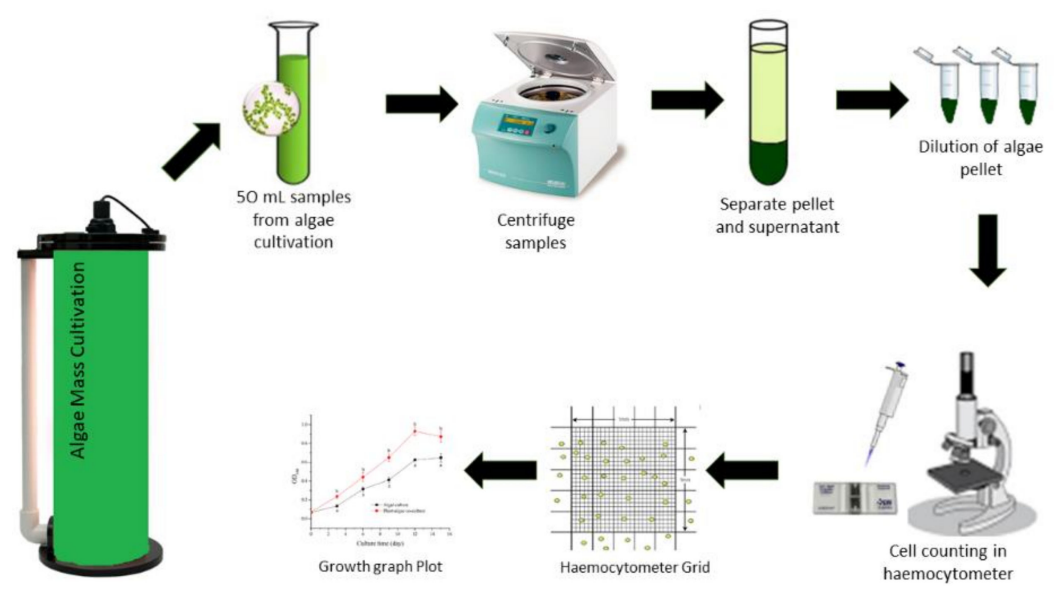

Figure 1. Microalgae cell counting for growth rate determination. 
Based on Figure 1, the microalgae cell concentration was calculated using Equation (1), where $D_{f}$ was the dilution factor of microalgae. Microalgae growth rates were measured based on maximum growth rate $\left(\mu_{\max }\right)$, division per day $\left(D_{d}\right)$ and doubling time $\left(t_{d}\right)$ according to the Equations (2), (3) and (4), respectively, where $X_{m}$ is a maximum cell number, $X_{0}$ is an initial cell number, $t_{m}$ is the day of maximum cell number and $t_{0}$ is day of initial cell number.

$$
\begin{gathered}
\text { Concentration algae }(\text { cell } / \mathrm{mL})=\text { Average no of cell } \times D_{f} \times 10^{4} \\
\text { Maximum growth rates }\left(\mu_{\max }\right)=\left(\operatorname{In}\left(X_{m}-X_{0}\right)\right) /\left(t_{m}-t_{0}\right) \\
\text { Division per day }\left(D_{d}\right)=\mu_{\max } / \operatorname{In} 2 \\
\text { Doubling time }\left(t_{d}\right)=1 / D_{d}
\end{gathered}
$$

Anand and Arumugam [36] studied Scenedesmus quadricauda growth in Bold's basal medium (BBM) medium rich in nitrogen and in nitrogen-depleted medium to evaluate the effect of nitrogen on cell growth and cell density. The cell number was determined for 30 days and at every three (3)-day interval, using hemocytometer microscopic cell count. The study result reported that $S$. quadricauda-specific growth rates and doubling time were higher in nitrogen-rich conditions $(0.33 \mu / \mathrm{d}, 2.09 / \mathrm{d})$ compared to nitrogen-depleted conditions $(0.14 \mu / d, 4.93 / d)$. Thus, the reports indicate that microalgae growth density was directly proportional in the presence of nitrogen $[3,35,40]$ and nutrient manipulation is the most efficient tool for the modulation of microalgae growth and biomass composition [26].

\subsection{Biomass Quality}

Microalgae are a promising source of food, biofuel, animal feed, fertilizer, cosmetics and also pharmaceuticals (Figure 2). The quality of these bioproducts depends on the quality of microalgae biomass composition. Microalgae biomass can be quantified by using several techniques such as cell counting, determination of volume, optical density and weight $[64,69]$. Generally, microalgae biomass and its quality are closely related to microalgae growth rates. A higher growth rate would provide higher microalgal biomass in a short period of time.

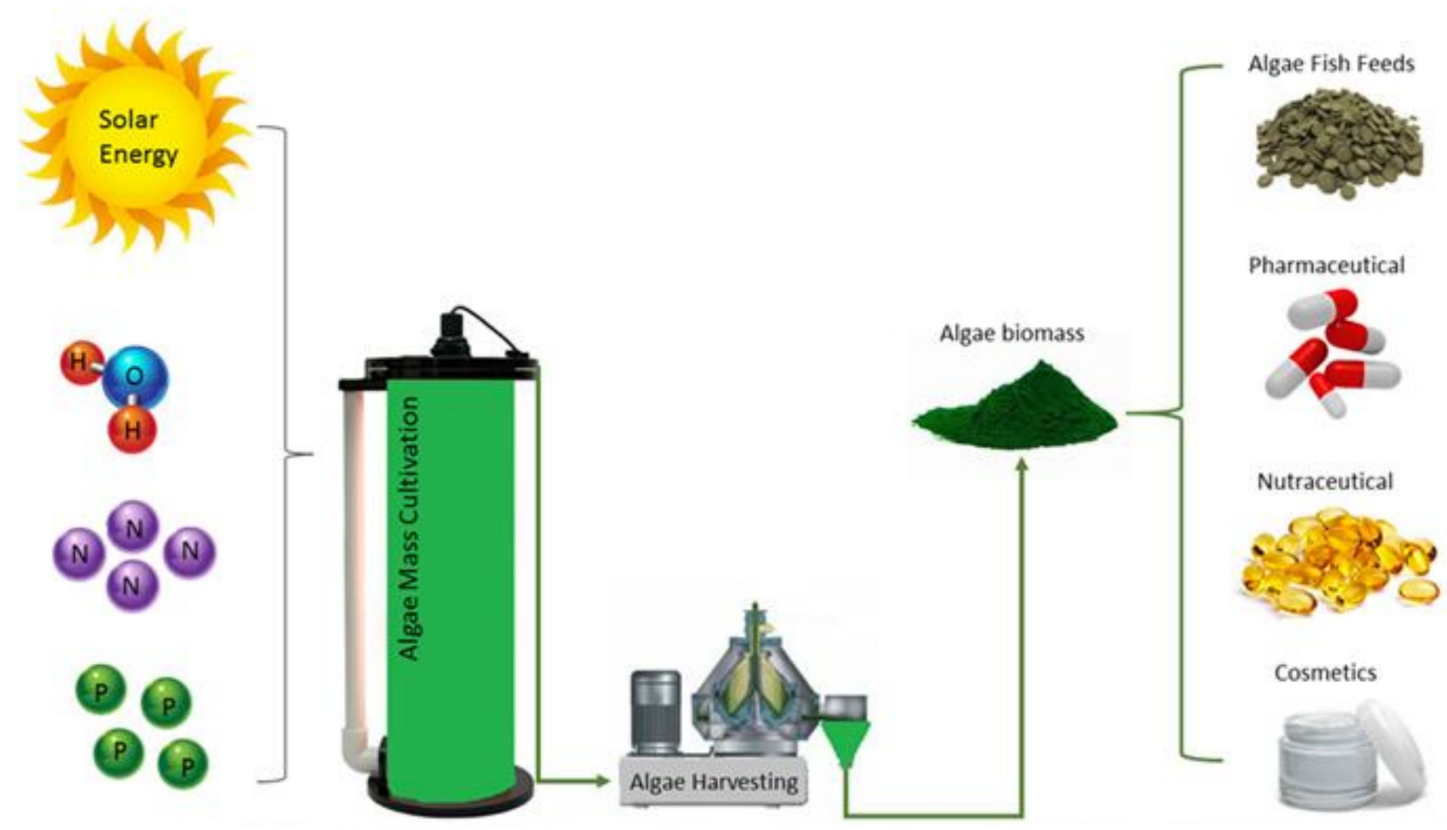

Figure 2. Microalgae cultivation with availability of essential nutrients and potential bioproducts. 
To measure microalgae biomass, microalgae culture may be filtered through a preweighed Whatman GF/C filter paper and then the filter paper is dried in an oven $[3,6,18,24]$. The difference between the final weight and weight before filtration is the dry biomass weight of the microalgae. Besides that, microalgae biomass also can be determined by sun drying as illustrated in Figure 3. However, the sun drying method is not effective in high humidity countries due to the high water content in microalgae biomass, often leading to unpleasant odors due to potential bacterial contamination [61].

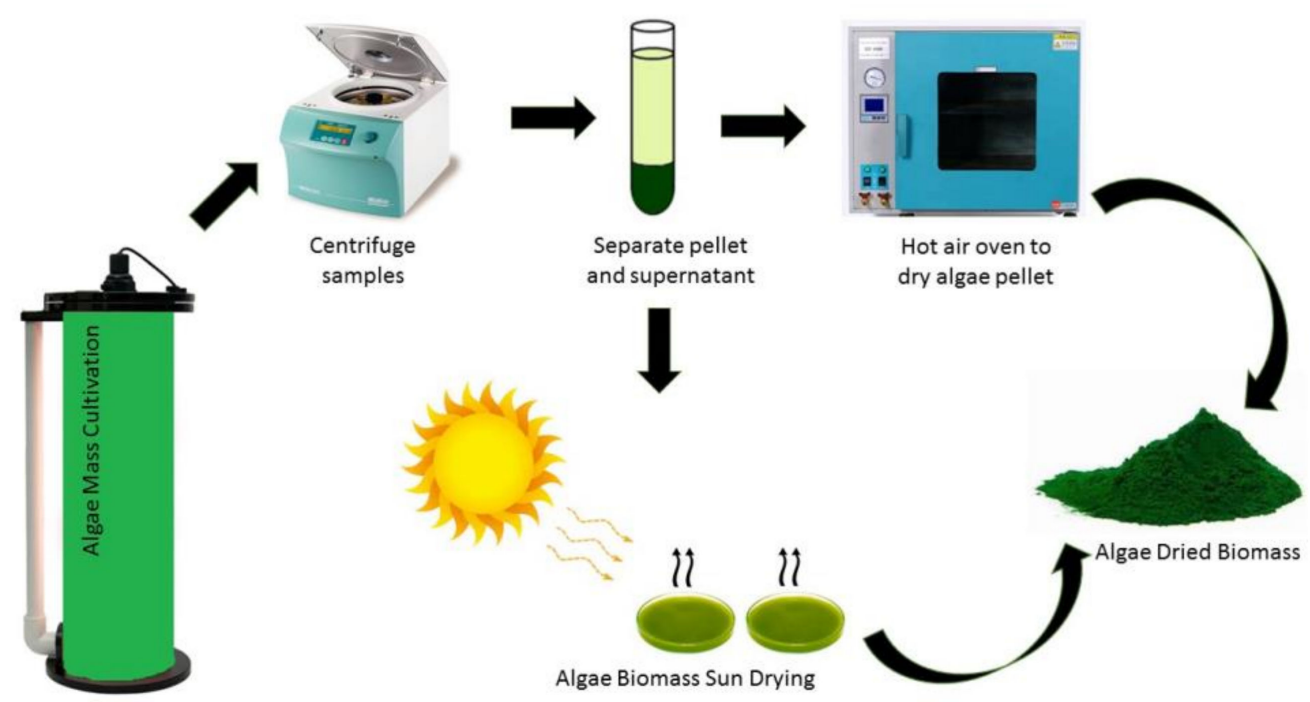

Figure 3. Microalgae harvesting and biomass production.

Microalgae biomass productivity is dividing the biomass with number of cells concentration in culture. Microalgae biomass productivity can be determined according to kinetic parameter Equation (5), where $\mu_{\max }$ is the maximum microalgae growth rate, $X_{0}$ is initial cell concentration and $X_{m}$ is maximum cell concentration in culture. The productivity was recorded in cells per milliliter per day (cells/mL/day).

$$
\text { Biomass productivity }=\left(\mu_{\max }\left(0.9 X_{m}-1.1 X_{0}\right)\right) /\left(\operatorname{In}\left(9\left(X_{m}-1.1 X_{0}\right) /\left(1.1 X_{0}\right)\right)\right)
$$

Generally, the productivity of biomass and lipid is influenced by nutrients and environmental factors [70]. In normal cultivation conditions, starch is the primary energy storage form in the photosynthetic fixation of carbon dioxide [71,72]. Starch stored in chloroplasts provides energy for vital metabolic processes, besides functioning as a carbon storage sink [71].

In nutrient depletion conditions, the microalgae growth and cellular division were inhibited, diverting the storage carbon to metabolic processes away from growth [71,72]. Starch accumulation can be an indicator of the balance between material and energy supply during the photosynthesis process. On the other hand, starch production decreased dramatically during nuclear and cellular divisions (growth process) as indicated in cytological studies [71]. This condition was able to divert stored carbon to lipid metabolism and to produce a range of secondary compounds. Lipids are another means of energy and carbon storage [72]. The shift from primary storage to secondary storage was due to lipid characteristics that are mainly made up of saturated and monounsaturated fatty acids which can be packed into the cell and generate more energy via oxidation than starch [71,73].

The decrease in the content of chlorophyll pigment is known as chlorosis and it is associated with nutrient depletion. Chlorophylls give microalgae a bright green color [71] and the diversion of microalgae starch production to lipid accumulation is initiated by carbon metabolism flux, also known as the oleaginicity process. The microalgae cells stopped growth and did not divide once the cultivation medium was completely depleted in nutrients, even though they had sufficient energy reserves to perform reproduction (cell 
division) [72]. Studies by Fernandes et al. [73] reported that starch content in Parachlorella kessleri decreased from $25 \%$ to $10 \%$ of dry weight (DW), while lipids increased from $0 \%$ to $29 \%$ of DW. Oleaginicity of central carbon metabolism could influence carbon partitioning towards TAG synthesis and thus reduce microalgae growth rate because TAG synthesis requires a carbon supply that supports microalgae growth, such as acetyl-CoA and glycerol 3-phosphate (G3P) [74]. G3P is derived from dihydroxyacetone phosphate (DHAP) produced from the Calvin cycle and glycolysis. Whereas, acetyl-CoA is a central metabolite for biochemical reactions, linked with anabolism and catabolism of TAG synthesis and the tricarboxylic acid (TCA) cycle [70,74].

TAG synthesis is an efficient way to protect against the production of reactive oxygen, photodamage of microalgal cells and protection against stressful conditions inducing nutrient deficiency conditions [68]. TAG was overproduced when their growth was retarded due to nutrient limitation but still had sufficient energy and carbon for metabolism. Generally, this condition triggered higher lipid production, leading to higher saturation of fatty acid [68].

It is ideal to achieve high microalgae productivity (biomass) and a high content of carbon and energy storage in terms of starch and lipids for industrial application [72]. Moreover, the algal biomass could be used for the production of bioenergy such as biogas, biofuel and biomethane, which can be an alternative renewable energy source instead of fossil fuels.

\section{Microalgae Lipids and Fatty Acids Extraction Methods}

The lipid extraction method is an important process for the production of microalgae biofuels and there are several techniques used to determine lipids and fatty acids concentration from microalgae biomass such as supercritical fluids, pressurized solvent extraction, infrared spectroscopy and gas chromatography-mass spectrometry (GC-MS). This subsection will critically discuss analytical techniques previously used by researchers to extract lipid and fatty acids.

\subsection{Lipids Extraction Methods}

Lipids are essential compounds in the microalgae biomass as they comprise triacylglycerols (TAG), phospholipids and glycolipids $[2,5,68]$, which are essential for metabolic activities and biofuel production. Usually, microalgae were associated with high costs for biomass downstream processing for oil extraction. Thus, it is important to extract lipids from microalgae cells using suitable technology that is cost-effective and environmentally friendly. Several methods were applied to quantify lipids from microalgae such as near infrared spectroscopy at specific wavelengths, electroporation, the supercritical fluid extraction method (SEF), pressurized solvent extraction, organic solvent and also osmotic shock $[2,64,75]$ as in Table 5 .

Kumar et al. [64] stated that electroporation, pressurized solvent extraction and the supercritical fluid extraction method are the most efficient technologies to extract lipids from microalgae biomass. However, they required high energy with high operational costs. Generally, cost-effective methods are used for lipid extraction such as osmotic shock, organic solvents through Soxhlet extraction, Bligh-Dyer method and Folch method [18,24,75].

According to King, [76] the supercritical fluid extraction method (SEF) can be used to extract lipids without using any organic solvent for analysis. This SEF method requires high energy consumption that is expensive for commercialization. The SEF method can separate lipids according to properties, enrichment, hydrogenation and hydrolysis. Figure 4 illustrates microalgae lipid extraction using SEF methods. Santana et al. [77] reported the use of the SEF method to extract lipids from Botryococcus braunii for biodiesel production. They observed that the lipid yield decreased with an increase in the temperature of extraction. However, the pressure enhancement has a positive influence on lipids productivity. The optimum operating conditions for SEF was in the range of 220-250 bar for pressure and $50{ }^{\circ} \mathrm{C}$ for temperature, respectively. Similar results were carried out in Nannochloropsis 
salina, Scenedesmus obliquus and Scenedesmus obtusiusulus for extraction of lipids to generate biodiesel [52,78]. SEF optimum conditions to generate $92 \%$ of lipids was performed at $12 \mathrm{MPa}, 20^{\circ} \mathrm{C}$, and a $\mathrm{CO}_{2}$ to biomass ratio of 100 [52].

Table 5. Techniques used to quantify lipids in microalgae [64].

\begin{tabular}{|c|c|c|c|}
\hline Types of Extraction Method & Advantages/Efficiency & Key Methodology & Drawbacks \\
\hline \multicolumn{4}{|c|}{ Mechanical Approach } \\
\hline Expeller press & $\begin{array}{l}\text { Simple and effective } \\
\text { crushing method }\end{array}$ & $\begin{array}{l}\text { High mechanical pressure to } \\
\text { crush the cells and squeeze oil } \\
\text { out from microalgae biomass }\end{array}$ & $\begin{array}{l}\text { Pressure decreased lipid } \\
\text { recovery, increased heat; } \\
\text { expensive and } \\
\text { time-consuming }\end{array}$ \\
\hline Ultrasound-assisted extraction & $\begin{array}{l}\text { Economical and eco-friendly, } \\
\text { completed in a short time, } \\
\text { high reproducibility, does not } \\
\text { require the addition of beads } \\
\text { or chemicals }\end{array}$ & $\begin{array}{l}\text { Cavitation produces heat } \\
\text { shock waves to disrupt } \\
\text { microalgae cells with less } \\
\text { thermal denaturation } \\
\text { of biomolecules }\end{array}$ & $\begin{array}{l}\text { Expensive, leads to free } \\
\text { radicals and detrimental to } \\
\text { the oil quality }\end{array}$ \\
\hline Bead beating & Moderate efficiency & $\begin{array}{l}\text { Disruption of cells using } \\
\text { high-speed spinning beads }\end{array}$ & Moderate efficiency \\
\hline $\begin{array}{l}\text { Microwaves } \\
\text { irradiation method }\end{array}$ & $\begin{array}{l}\text { Short reaction time, low costs, } \\
\text { efficient extraction and quick } \\
\text { oil recovery }\end{array}$ & $\begin{array}{c}\text { Extraction and } \\
\text { transesterification of the oils } \\
\text { into biodiesel by intracellular } \\
\text { heating, which } \\
\text { disrupts the cells }\end{array}$ & $\begin{array}{l}\text { High maintenance cost on a } \\
\text { large scale. }\end{array}$ \\
\hline Electroporation & High efficiency & $\begin{array}{l}\text { Altered cell membranes and } \\
\text { cell walls to improved } \\
\text { lipid extraction }\end{array}$ & $\begin{array}{l}\text { High initial and } \\
\text { maintenance costs }\end{array}$ \\
\hline \multicolumn{4}{|c|}{ Chemical Approach } \\
\hline $\begin{array}{l}\text { Supercritical fluid extraction } \\
\text { method (SEF) }\end{array}$ & $\begin{array}{l}\text { Rapid, safe and economical } \\
\text { method and does not require } \\
\text { dewatering of biomass }\end{array}$ & $\begin{array}{l}\text { Using high pressure to extract } \\
\text { lipids from cells }\end{array}$ & $\begin{array}{l}\text { High cost and environmental } \\
\text { and safety issues }\end{array}$ \\
\hline Bligh and Dyer method & $\begin{array}{l}\text { Rapid and easy processing of } \\
\text { large number of samples }\end{array}$ & $\begin{array}{l}\text { Extracting total lipids from } \\
\text { microalgae using ratio 2:1 } \\
\text { methanol: chloroform }\end{array}$ & Less sensitive \\
\hline Pressurized solvent extraction & High efficiency & $\begin{array}{l}\text { Using solvent and pressurized } \\
\text { nitrogen for extraction }\end{array}$ & $\begin{array}{l}\text { High cost, fire, health and } \\
\text { environmental hazards }\end{array}$ \\
\hline Folch method & $\begin{array}{l}\text { Rapid and easy processing of } \\
\text { large number of samples }\end{array}$ & $\begin{array}{l}\text { Combination of different } \\
\text { solvents such as } \\
\text { chloroform-methanol in the } \\
\text { ratio of } 2: 1 \text { by volume }\end{array}$ & Less sensitive \\
\hline Soxhlet extraction method & $\begin{array}{l}\text { Easy processing of a large } \\
\text { number of samples and } \\
\text { moderate efficiency }\end{array}$ & $\begin{array}{l}\text { Normally used to quantify } \\
\text { high quality lipids such as } \\
\text { fatty acids and triglycerides } \\
\text { using hexane as a solvent }\end{array}$ & $\begin{array}{l}\text { Environmental and } \\
\text { health risks }\end{array}$ \\
\hline $\begin{array}{l}\text { Accelerated solvent extraction } \\
\text { (ASE) }\end{array}$ & $\begin{array}{l}\text { Short process time and can } \\
\text { recover solvent for reuse }\end{array}$ & $\begin{array}{l}\text { Using heat or pressure to } \\
\text { achieve better lipid recovery }\end{array}$ & Less efficient in a larger scale \\
\hline
\end{tabular}




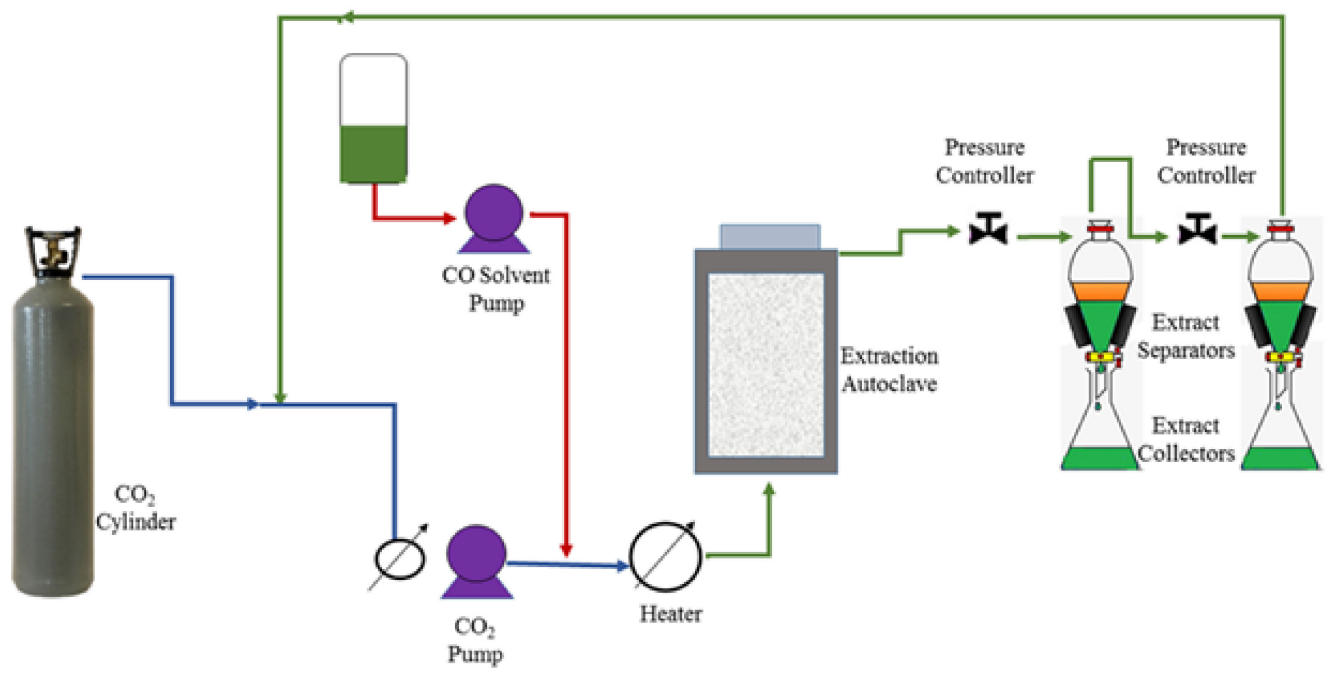

Figure 4. Microalgae supercritical fluid extraction method.

Other than SEF, the most common methods used for lipid extraction are modified Folch and Bligh and Dyer methods as shown in Figure 5. The harvested microalgae biomass was added with methanol and chloroform $(2: 1 \mathrm{v} / \mathrm{v})$ for lipid extraction. Then, lipid extracts were washed with $0.9 \%$ saline followed by vortex and separation phase either using thin layer chromatography (TLC) or chromatography (GC-MS). Zienkiewicz et al. [8] followed this method for Nannochloropsis oceanica: total lipid quantification and after centrifugation separation, lipids were visualized by thin layer chromatography (TLC). Similarly, Vooren et al. [24] had measured lipid content in Nannochloropsis oculata using the Bligh and Dyer extraction method followed by high performance thin layer chromatography (HP-TLC). Vooren et al. [24] showed that C. zofingiensis cultivated under nitrogen starvation conditions produced triglycerides in the range of $31 \%$ to $43 \%$ due to a shift in cell metabolism. Zhu et al. [3] used GC-MS to analyze lipid content in C. zofingiensis. The Folch et al. [79] and Bligh and Dyer [80] methods were used for total lipid recovery and extraction was used; it was widely performed by researchers due to the simple procedures, time efficiency, energy savings and suitability for a large sample size.

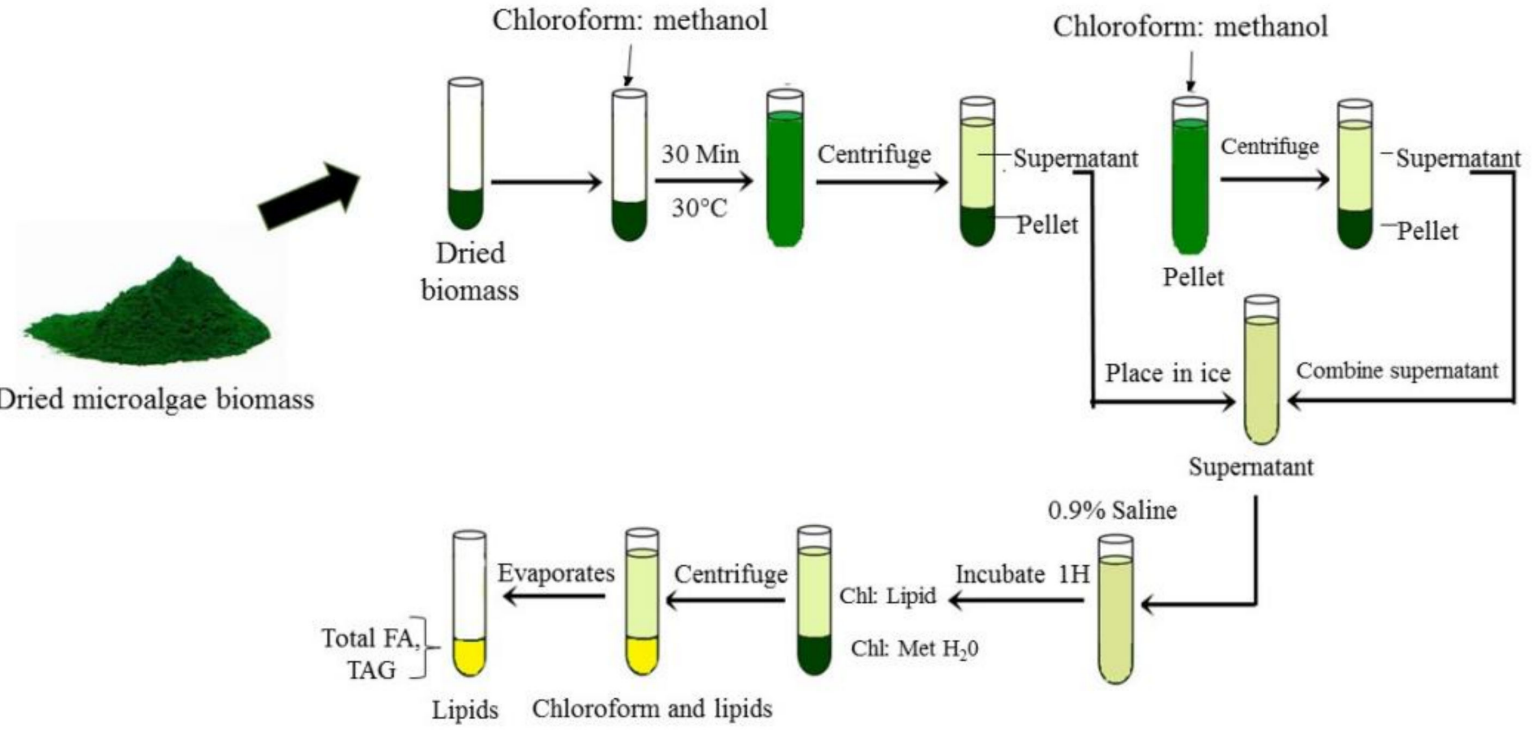

Figure 5. Microalgae lipid extraction by Bligh and Dyer and Folch methods. 
Another promising method for lipid extraction was an osmotic shock that degrades microalgae cell structures to increase lipid yield efficiency. Gonzalez-Gonzaález et al. [81] studied the effect of osmotic shock on Dunaliella salina and Chaetoceros muelleri for biogas (methane) generation. The study reported that $C$. muelleri lipid recovery efficiency for methane production was higher than D. salina with $72 \%$ and $21 \%$, respectively. Microalgae biomass can be used for biomethane generation through anaerobic digestion or the biomass gasification and methanation process. Biomass produced in limited nitrogen culture media was more stable with low inhibitory substances such as ammonia which caused acidosis. Microalgae with high lipids content will yield greater volumes of biomethane than microalgae rich in carbohydrates and protein [82]. Klassen et al. [83] reported that high biomethane productivity was achieved under nitrogen-limited biomass conditions with $462 \pm 9 \mathrm{mLN} \mathrm{CH}_{4} \mathrm{~g}^{-1} \mathrm{VS}_{\mathrm{day}}{ }^{-1}$ and the biomass-to-biomethane energy conversion efficiency was up to $84 \%$.

Similarly, Yoo et al. [75] reported that osmotic shock enhanced the lipid recovery by two-fold in wet biomass of Chlamydomonas reinhardtii. In this technique, microalgae biomass was mixed with hexane, chloroform and methanol solvent in the Teflon-sealed tubes for $10 \mathrm{~min}$ for better lipid recovery since hexane and methanol required low heat for evaporation and rupture of microalgae cells [75]. It concluded that an osmotic shock is a promising technique for microalgae lipid extraction recovery from wet biomass.

\subsection{Fatty Acids Extraction Method}

Fatty acids (FA) are carboxylic acids with an aliphatic chain consisting of 4-26 carbons, joined by either saturated or unsaturated bonds [68]. There are several techniques to extract fatty acids from the microalgae biomass and convert it into fatty acid methyl ester (FAME) using gas chromatography-mass spectrometry (GC-MS), followed by subjecting it to a direct transesterification method; also, there is the Microbial identification (MIDI) system, Newark, Delaware, USA, the gravimetric method and the modified one-step in situ transesterification method (IST).

A modified one-step in situ transesterification method (IST) was used to quantify fatty acid methyl ester (FAME) and it has been used by Zarrinmehr et al. [7] and Tang et al. [84]. Transesterification is the most common, less energy-consuming process to exchange preexistent ester linkage using an acid or basic catalyst to release methanol and glycerol from synthesized fatty acid methyl esters [24]. According to Tang et al. [84], transesterification was related to the direct conversion of microalgal lipids into fatty acid methyl esters (FAME), either using acid or alkaline catalysts. This IST can be performed without lipid extraction technique (Figure 6). Besides that, this IST technique was widely used due to the high accuracy, simplicity and reliability. Generally, saturated fatty acids (SFA) possess a high cetane number and better oxidative stability. Microalgae with a high percentage of C18:1 were valuable components for biofuel production [85]. Higher cetane number is a prerequisite for reduced $\mathrm{NO}_{2}$ emission to the atmosphere [86]. According to Praveenkumar et al. [86], Chlorella sp. had potential as an alternative to biodiesel when cultivated in nitrogen-deficient conditions compared to phosphorus-limited conditions. An increase in unsaturated fatty acids is usually undesirable for biofuel production as it leads to a low cetane number, thereby enhancing $\mathrm{NO}_{2}$ emission, oxidation and lubricity of biofuels [86]. Hence, the biofuels must have a high amount of saturated and monounsaturated fatty acids with low levels of polyunsaturated fatty acids.

Nannochloropsis gaditana contained a high amount of eicosapentaenoic acid (EPA), followed by docosahexaenoic acid (DHA) content [84]. The $c$ FAME yield of $N$. gaditana was $10.04 \% \pm 0.08 \%$ by weight, with the EPA yields as high as $4.02 \% \pm 0.17 \%$ by dry weight, which is approximately two times higher than the conventional method. 


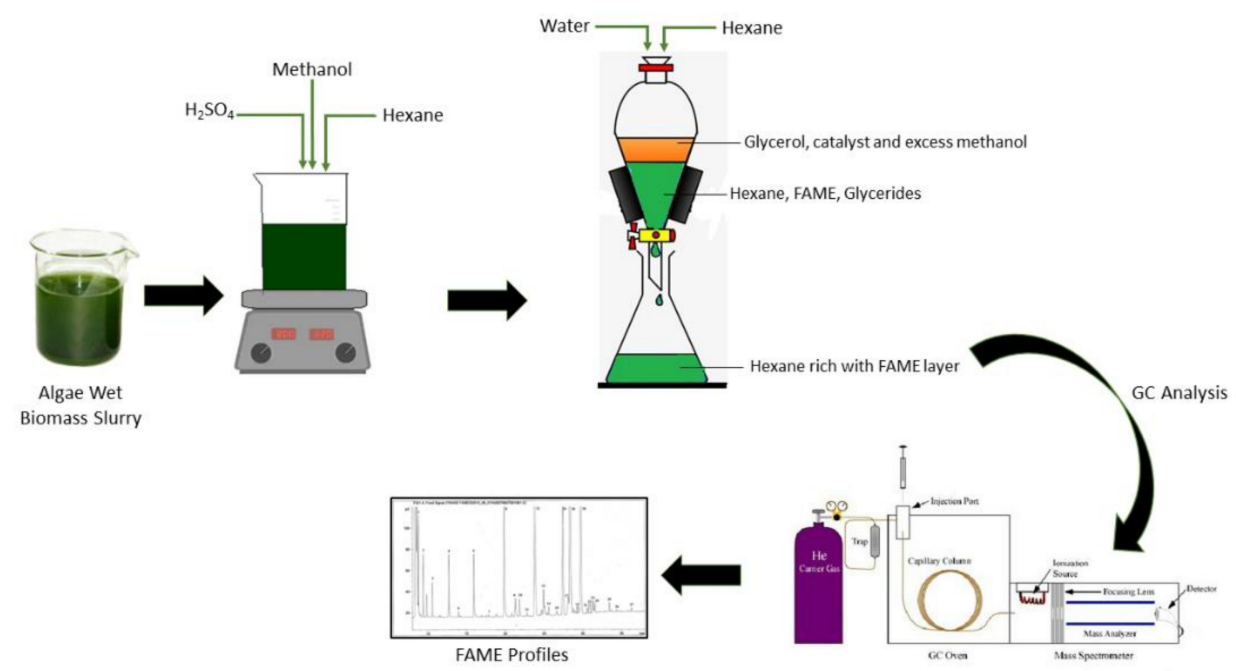

Figure 6. Microalgae fatty acids in situ transesterification.

Besides that, another technique that is commonly used to quantify FAME is gas chromatography-mass spectrometry (GC-MS). Microalgae biomass was extracted first using solvents, and an aliquot of extraction was injected into the GC-MS capillary column at a specific time and pressure for the determination of fatty acid profile. Prommuak et al. [87] reported the fatty acids profile in C. vulgaris using GC-MS technique wherein the highest FAME obtained were methyl linoleate, methyl palmitate, methyl oleate and methyl stearate. Similarly, the study recorded that under nitrogen deprivation conditions, Chlorella sp. showed high amounts of saturated and monounsaturated fatty acids containing $36.45 \%$ stearic acid, $16.78 \%$ arachidic acid, $7.02 \%$ heneicosanoic acid and $19.91 \%$ linoleic acid. This study concludes that nitrogen starvation is suitable for the synthesis of high quality fatty acids for sustainable biodiesel production [86].

Cointet et al. [38] reported that FAME from Entomoneis paludosa, Nitzschia alexandrina and Staurosira sp. directly undergo transesterification using hydrochloric methanol and chloroform as solvent. The studies reported that the most abundant saturated fatty acid (SFA) was palmitic acid (C16:0), ranging from $32.5 \pm 4.3 \%$ to $64.6 \pm 6.0 \%$ for all strains in nitrogen-limited treatment. Whereas, the highest unsaturated fatty acid was oleic acid for E. paludosa $(20.1 \pm 3.2 \%)$ and palmitoleic acid for N. alexandrina and Staurosira sp., with $25.2 \pm 1.9 \%$ and $25.0 \pm 9.0 \%$, respectively [38].

Finally, FAME also can be analyzed using the MIDI system (Microbial ID, Newark, Delaware) as reported by Mulbry et al. [52]. They found that fatty acid content in algal turf scrubber (ATS) consisted of C14:0, 16:0, 16:1.7, 16:1.9, 18:0, 18:1.9, 18:2.6 and 18:3.3 when analyzed by the MIDI system. Figure 7 shows microalgae FAME analysis using the MIDI microbial ID technique.

The MIDI microbial identification system is a fully automated gas chromatographic analytical system, which identifies microalgae strains and bacteria based on their unique 9 to 20 carbons in length fatty acid profiles. Four reagents are required to cleave the fatty acids from lipids that involve several phases such as the saponification phase (sodium hydroxide, methanol and distilled water), methylation phase (hydrochloric acid and methyl alcohol), extraction phase (hexane and methyl tert-butyl ether) and sample cleanup phase (sodium hydroxide solution) before samples are injected to the GC port liner for analysis. The MIDI-FAME profile is an effective, rapid technique, and does not require concentrated biomass to be transferred from vial to vial $[52,88,89]$. 


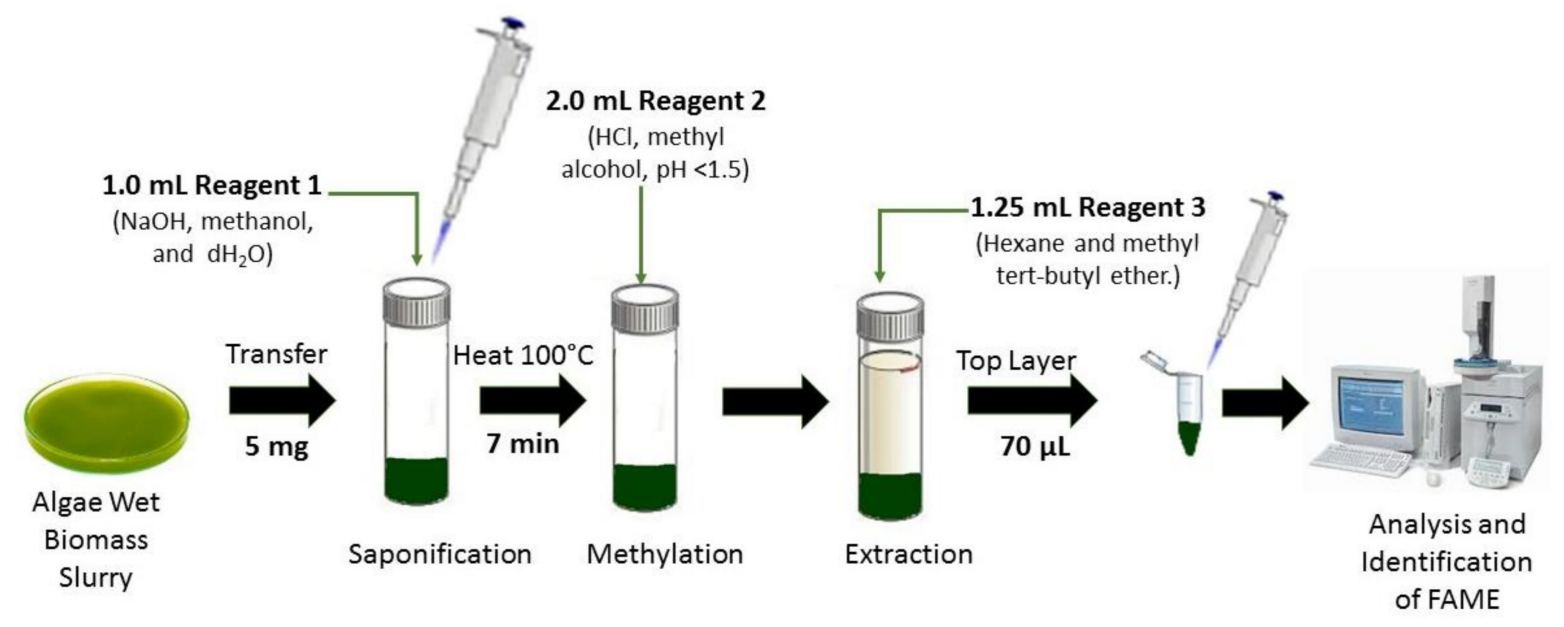

Figure 7. Microalgae fatty acids by Microbial Identification (MIDI) system.

\section{Conclusions}

This review has attempted to give an insight of the roles of nitrogen and phosphorus in microalgae cultivation for growth, biomass production, lipid yields and fatty acids. It gives a clear idea to the reader on how nutrients play a vital role in microalgae growth and their effects on biochemical composition. Microalgae exhibit higher growth rates and biomass production which might be an alternative source for bioproducts due to their high levels of lipids and fatty acids content in the cells. Besides that, cultivation media containing a high amount of nitrogen and phosphorus are more suitable for microalgae growth rates and for biomass production. Nutrient-limited conditions are more efficient for lipid and fatty acids generation. Other than that, suitable extraction techniques shall be implemented to achieve optimum lipid and fatty acids yield, reduce cost and have better bioproduct quality. All future research shall look into the optimization of nutrients in microalgae cultivation so that there will be more bioproduct generation and it can be commercialized for better usage in food, feed, fertilizer, nutraceutical and pharmaceutical applications.

Author Contributions: M.A.Y. was the main researcher who has contributed significantly in this paper, collecting and analyzing the information, writing the manuscript. The authors R.M.S.R.M., A.A.-G., R.A.G. and R.R.A. edited the manuscript and approved the final version. All authors have read and agreed to the published version of the manuscript.

Funding: This research was funded by the Ministry for Higher Education Malaysia for the 'Research Excellence Consortium' with the grant title Research Consortium for Wastewater Resource Recovery (RCWRR) with reference JPT(BKPI)1000/016/018/25 (56), Project Satellite No. 3 (UTHM): Resource Recovery from Domestic Wastewater by Microalgae Scenedesmus sp. for Bio-Product and Water Reuse.

Acknowledgments: The authors would like to acknowledge and thankful to Universiti Tun Hussein Onn Malaysia (UTHM), especially the Institute for Integrated Engineering $\left(\mathrm{I}^{2} \mathrm{E}\right)$ and Micropollutant Research Centre (MPRC), Faculty of Civil Engineering and Built Environment (FKAAB) for support in this research. R.R.A. acknowledges Vignan's Foundation for Science, Technology and Research (deemed to be University) for providing the facility for this work.

Conflicts of Interest: The authors declare no conflict of interest. 


\section{References}

1. Sirakov, I.; Velichkova, K.; Stoyanova, S.; Staykov, Y. The importance of microalgae for aquaculture industry. Review. Int. J. Fish. Aquat. Stud. 2015, 2, 81-84.

2. Maizatul, A.Y.; Mohamed, R.M.S.R.; Al-Gheethi, A.A.; Hashim, M.A. An overview of the utilisation of microalgae biomass derived from nutrient recycling of wetmarket wastewater and slaughterhouse wastewater. Int. Aquat. Res. 2017, 9, 177-193. [CrossRef]

3. Zhu, S.; Huang, W.; Xu, J.; Wang, Z.; Xu, J.; Yuan, Z. Metabolic changes of starch and lipid triggered by nitrogen starvation in the microalga Chlorella zofingiensis. Bioresour. Technol. 2014, 152, 292-298. [CrossRef] [PubMed]

4. Yang, L.; Chen, J.; Qin, S.; Zeng, M.; Jiang, Y.; Hu, L.; Xiao, P.; Hao, W.; Hu, Z.; Lei, A.; et al. Growth and lipid accumulation by different nutrients in the microalga Chlamydomonas reinhardtii. Biotechnol. Biofuels 2008, 11, 40. [CrossRef]

5. Yodsuwan, N.; Sawayama, S.; Sirisansaneeyakul, S. Effect of nitrogen concentration on growth, lipid production and fatty acid profiles of the marine diatom Phaeodactylum tricornutum. Agric. Nat. Resour. 2017, 51, 190-197. [CrossRef]

6. Yang, F.F.; Xiang, W.; Li, T.; Long, L. Transcriptome analysis for phosphorus starvation-induced lipid accumulation in Scenedesmus sp. Sci. Rep. 2018, 8, 1-11. [CrossRef]

7. Zarrinmehr, M.J.; Farhadian, O.; Heyrati, F.P.; Keramat, J.; Koutra, E.; Kornaros, M.; Daneshvar, E. Effect of nitrogen concentration on the growth rate and biochemical composition of the microalga, Isochrysis galbana. Egypt. J. Aquat. Res. 2019, 46, 1687-4285. [CrossRef]

8. Zienkiewicz, A.; Zienkiewicz, K.; Poliner, E.; Pulman, J.A.; Du, Z.-Y.; Stefano, G.; Tsai, C.H.; Horn, P.; Feussner, I.; Farre, E.M.; et al. The microalga Nannochloropsis during transition from quiescence to qutotrophy in response to nitrogen availability. Plant Physiol. 2020, 182, 819-839. [CrossRef] [PubMed]

9. Jais, N.M.; Mohamed, R.M.S.R.; Al-Gheethi, A.A.; Hashim, A. Dual role of phycoremediation of wet market wastewater for nutrients and heavy metals removal and microalgae biomass production. Clean. Technol. Environ. Policy. 2016, 19, 37-52. [CrossRef]

10. Yaakob, M.A.; Mohamed, R.M.S.R.; Al-Gheethi, A.; Athirah, A.; Kassim, A.H.M. Optimising of Scenedesmus sp. biomass production in chicken slaughterhouse wastewater using response surface methodology and potential utilisation as fish feeds. Environ. Sci. Pollut. Res. 2019, 26, 12089-12108. [CrossRef]

11. Kim, M.K.; Park, J.W.; Park, C.S.; Kim, S.J.; Jeune, K.H.; Chang, M.U.; Acreman, J. Enhanced production of Scenedesmus spp. (green microalgae) using a new medium containing fermented swine wastewater. Bioresour. Technol. 2007, 98, 2220-2228. [CrossRef]

12. Abou-Shanab, R.A.I.; Ji, M.K.; Kim, H.C.; Paeng, K.J.; Jeon, B.H. Microalgal species growing on piggery wastewater as a valuable candidate for nutrient removal and biodiesel production. J. Environ. Manage. 2013, 115, 257-264. [CrossRef]

13. Brown, M.R. Nutritional value of microalgae for aquaculture. In Advances in Aquaculture nutrition, Proceedings of the VI International Symposium on Nutrition Aquaculture, Cancun, Quintana Roo, Mexico 3-6 September 2002; Cruz-Suarez, L.E., Ricque-Marie, D., Tapia-Salazar, M., Gaxiola-Cortés, M.G., Simoes, N., Eds.; Universidad Autónoma De Nuevo León: Monterey, Mexico, 2002.

14. Hemaiswarya, S.; Raja, R.; Kumar, R.R.; Ganesan, V.; Anbazhagan, C. Microalgae: A sustainable feed source for aquaculture. World J. Microbiol. Biotechnol. 2011, 27, 1737-1746. [CrossRef]

15. Spolaore, P.; Joannis-Cassan, C.; Duran, E.; Isambert, A. Commercial applications of microalgae. J. Biosci. Bioeng. 2006, 101, 87-96. [CrossRef]

16. Hakalin, N.L.S.; Paz, A.P.; Aranda, D.A.G.; Moraes, L.M.P. Enhancement of cell growth and lipid content of a freshwater microalga Scenedesmus sp. by optimizing nitrogen, phosphorus and vitamin concentrations for biodiesel production. Nat. Sci. 2014, 6, 1044-1054. [CrossRef]

17. Baharuddin, N.N.D.E.; Azizi, N.S.; Sohif, H.N.; Karim, W.A.B.; Al-Obaidi, J.R.; Basiran, M.N. Marine microalgae flocculation using plant: The case of Nannochloropsis oculata and Moringa oleifera. Pak. J. Bot. 2016, 48, 831-840.

18. Xin, L.; Hong-ying, H.; Ke, G.; Ying-xue, S. Effects of different nitrogen and phosphorus concentrations on the growth, nutrient uptake, and lipid accumulation of a freshwater microalga Scenedesmus sp. Bioresour. Technol. 2010, 101, 5494-5500. [CrossRef]

19. Singh, J.; Gu, S. Commercialization potential of microalgae for biofuels production. Renew. Sustain. Energy Rev. 2010, 14, 2586-2610. [CrossRef]

20. Zhang, Q.; Hong, Y. Comparison of growth and lipid accumulation properties of two oleaginous microalgae under different nutrient conditions. Front. Environ. Sci. Eng. 2014, 8, 703-709. [CrossRef]

21. Arkronrat, W.; Deemark, P.; Oniam, V. Growth performance and proximate composition of mixed cultures of marine microalgae (Nannochloropsis sp. and Tetraselmis sp.) with monocultures. Songklanakarin J. Sci. Technol. 2016, 38, 1-5.

22. Munoz, R.; Guieysse, B. Algal-bacterial processes for the treatment of hazardous contaminants: A review. Water Res. 2006, 40, 2799-2815. [CrossRef]

23. Mansour, M.P.; Frampton, D.M.F.; Nichols, P.D.; Volkman, J.K.; Blackburn, S.I. Lipid and fatty acid yield of nine stationary-phase microalgae: Applications and unusual C24-C28 polyunsaturated fatty acids. J. Appl. Phycol. 2005, 17, 287-300. [CrossRef]

24. Vooren, G.V.; Grand, F.L.; Legrand, J.; Cuiné, S.; Peltier, G.; Pruvost, J. Investigation of fatty acids accumulation in Nannochloropsis oculata for biodiesel application. Bioresour. Technol. 2012, 124, 421-432. [CrossRef]

25. Xu, N.; Zhang, X.; Fan, X.; Han, L.; Zeng, C. Effects of nitrogen source and concentration on growth rate and fatty acid composition of Ellipsoidion sp. (Eustigmatophyta). J. Appl. Phycol. 2001, 13, 463-469. [CrossRef] 
26. Procházková, G.; Brányiková, I.; Zachleder, V.; Brányik, T. Effect of nutrient supply status on biomass composition of eukaryotic green microalgae. J. Appl. Phycol. 2013, 26, 1359-1377. [CrossRef]

27. Rodolfi, L.; Zittelli, G.C.; Bassi, N.; Padovani, G.; Biondi, N.; Bonini, G.; Tredici, M.R. Microalgae for oil: Strain selection induction of lipid synthesis and outdoor mass cultivation in a low-cost photobioreactor. Biotechnol. Bioeng. 2009, 102, 100-112. [CrossRef]

28. Chu, F.F.; Chu, P.N.; Cai, P.J.; Li, W.W.; Lam, P.K.S.; Zeng, R.J. Phosphorus plays an important role in enhancing biodiesel productivity of Chlorella vulgaris under nitrogen deficiency. Bioresour. Technol. 2013, 134, 341-346. [CrossRef] [PubMed]

29. Pancha, I.; Chokshi, K.; George, B.; Ghosh, T.; Paliwal, C.; Maurya, R.; Mishra, S. Nitrogen stress triggered biochemical and morphological changes in the microalgae Scenedesmus sp. CCNM 1077. Bioresour. Technol. 2014, 156, 146-154. [CrossRef] [PubMed]

30. Jia, J.; Han, D.; Gerken, H.G.; Li, Y.; Sommerfeld, M.; Hu, Q.; Xu, J. Molecular mechanisms for photosynthetic carbon partitioning into storage neutral lipids in Nannochloropsis oceanica under nitrogen-depletion conditions. Algal Res. 2015, 7, 66-77. [CrossRef]

31. Paes, C.R.P.S.; Faria, G.R.; Tinoco, N.A.B.; Castro, D.J.F.A.; Barbarino, E.; Lourenço, S.O. Growth, nutrient uptake and chemical composition of Chlorella sp. and Nannochloropsis oculata under nitrogen starvation. Lat. Am. J. Aquat. Res. 2016, 44, $275-292$. [CrossRef]

32. Patel, A.; Pruthi, V.; Pruthi, P.A. Synchronized nutrient stress conditions trigger the diversion of CDP-DG pathway of phospholipids synthesis towards de novo TAG synthesis in oleaginous yeast escalating biodiesel production. Energy 2017, 139, 962-974. [CrossRef]

33. An, M.; Gao, L.; Zhao, W.; Chen, W.; Li, M. Effects of nitrogen forms and supply mode on lipid production of microalga Scenedesmus obliquus. Energies 2020, 13, 697. [CrossRef]

34. Feng, P.; Deng, Z.; Fan, L.; Hu, Z. Lipid accumulation and growth characteristics of Chlorella zofingiensis under different nitrate and phosphate concentrations. J. Biosci. Bioeng. 2012, 114, 405-410. [CrossRef]

35. Breuer, G.; Lamers., P.P.; Martens, D.E.; Draaisma, R.B.; Wijffels, R.H. The impact of nitrogen starvation on the dynamics of triacylglycerol accumulation in nine microalgae strains. Bioresour. Technol. 2012, 124, 217-226. [CrossRef]

36. Anand, J.; Arumugam, M. Enhanced lipid accumulation and biomass yield of Scenedesmus quadricauda under nitrogen starved condition. Bioresour. Technol. 2015, 188, 190-194. [CrossRef] [PubMed]

37. Singh, P.; Guldhe, A.; Kumari, S.; Rawat, I.; Bux, F. Investigation of combined effect of nitrogen, phosphorus and iron on lipid productivity of microalgae Ankistrodesmus falcatus KJ671624 using response surface methodology. Biochem. Eng J. 2015, 94, 22-29. [CrossRef]

38. Cointet, E.; Wielgosz-Collin, G.; Bougaran, G.; Rabesaotra, V.; Goncalves, O.; Meleder, V. Effects of light and nitrogen availability on photosynthetic efficiency and fatty acid content of three original benthic diatom strains. PLoS ONE 2019, 14, e0224701. [CrossRef] [PubMed]

39. Latsos, C.; Houcke, J.V.; Timmermans, K.R. The effect of nitrogen starvation on biomass yield and biochemical constituents of Rhodomonas sp. Front. Mar. Sci. 2020, 7, 563333. [CrossRef]

40. Delgado, R.T.; Guarieiro, M.D.S.; Cassini, S.T.; Terreros, H.M.; Fernandes, V.D.O. Effect of nitrogen limitation on growth, biochemical composition and cell ultrastructure of the microalga Picocystis Salinarum. Preprint 2020. [CrossRef]

41. Savvidou, M.G.; Boli, E.; Logothetis, D.; Lymperopoulou, T.; Ferraro, A.; Louli, V.; Mamma, D.; Kekos, D.; Magoulas, K.; Kolisis, F.N. A study on the effect of macro- and micro-nutrients on Nannochloropsis oceanica growth, fatty acid composition and magnetic harvesting efficiency. Plants 2020, 9, 660. [CrossRef] [PubMed]

42. Ota, S.; Yoshihara, M.; Yamazaki, T.; Takeshita, T.; Hirata, A.; Konomi, M.; Oshima, K.; Hattori, M.; Bisova, K.; Zachleder, V.; et al. Deciphering the relationship among phosphate dynamics, electron-dense body and lipid accumulation in the green alga Parachlorella kessleri. Sci. Rep. 2016, 6, 25731. [CrossRef] [PubMed]

43. Hannon, M.; Gimpel, J.; Tran, M.; Rasala, B.; Mayfield, S. Biofuels from algae: Challenges and potential. Biofuels 2010, 1, 763-784. [CrossRef] [PubMed]

44. Atiku, A.; Mohamed, R.M.S.R.; Al-Gheethi, A.A.; Wurochekke, A.A.; Kassim, A.H. Harvesting microalgae biomass from the phycoremediation process of greywater. Environ. Sci. Pollut. Res. 2016, 23, 24624-24641. [CrossRef]

45. Solovchenko, A.; Gorelova, O.; Karpova, O.; Selyakh, I.; Semenova, L.; Chivkunova, O.; Baulina, O.; Vinogradova, E.; Pugacheva, T.; Scherbakov, P.; et al. Phosphorus feast and famine in Cyanobacteria: Is luxury uptake of the nutrient just a consequence of acclimation to its shortage. Cells 2020, 9, 1933. [CrossRef]

46. Goldberg, I.K.; Cohen, Z. The effect of phosphate starvation on the lipid and fatty acid composition of the fresh water eustigmatophyte Monodus subterraneus. Phytochemistry 2006, 67, 696-701. [CrossRef]

47. Roopnarain, A.; Gray, V.M.; Sym, S.D. Phosphorus limitation and starvation effects on cell growth and lipid accumulation in Isochrysis galbana U4 for biodiesel production. Bioresour. Technol. 2014, 156, 408-411. [CrossRef]

48. Jais, N.M.; Mohamed, R.M.S.R.; Apandi, W.A.W.M.; Peralta., H.M.M. Removal of nutrients and selected heavy metals in wet market wastewater by using microalgae Scenedesmus sp. Appl. Mech. Mater. 2015, 1210-1214. [CrossRef]

49. Satpati, G.G.; Gorain, P.C.; Pal, R. Efficacy of EDTA and phosphorous on biomass yield and total lipid accumulation in two green microalgae with special emphasis on neutral lipid detection by flow cytometry. Adv. Biol. 2016, 2016, 12. [CrossRef]

50. Lorenzen, J.; Igl, N.; Tippelt, M.; Stege, A.; Qoura, F.; Sohling, U.; Brück, T. Extraction of microalgae derived lipids with supercritical carbon dioxide in an industrial relevant pilot plant. Bioprocess Biosyst. Eng. 2017, 40, 911-918. [CrossRef] 
51. Anto, S.; Pugazhendhi, A.; Mathimani, T. Lipid enhancement through nutrient starvation in Chlorella sp. and its fatty acid profiling for appropriate bioenergy feedstock. Biocatal. Agric. Biotechnol. 2019, 20, 101179. [CrossRef]

52. Mulbry, W.; Kondrad, S.; Pizarro, C.; Kebede-Westhead, E. Treatment of dairy manure effluent using freshwater algae: Algal productivity and recovery of manure nutrients using pilot-scale algal turf scrubbers. Bioresour. Technol. 2008, 99, 8137-8142. [CrossRef] [PubMed]

53. Solovchenko, A.; Verschoor, A.M.; Jablonowski, N.D.; Nedbal, L. Phosphorus from wastewater to crops: An alternative path involving microalgae. Biotechnol. Adv. 2016, 34, 550-564. [CrossRef]

54. Salem, O.M.A.; El-Ardy, O.; Abd El-Rahman, M.A. Effect of Nitrogen and Phosphorus Concentrations in Growth Medium and Salt Stress on Growth, Lipid Content, and Biodiesel Producing Ability of Microalgae; Helwan University: Helwan, Egypt, 2013; pp. 17-18.

55. Liang, K.; Zhang, Q.; Gu, M.; Cong, W. Effect of phosphorus on lipid accumulation in freshwater microalga Chlorella sp. J. Appl. Phycol. 2013, 25, 311-318. [CrossRef]

56. Qari, H.A.; Oves, M. Fatty acid synthesis by Chlamydomonas reinhardtii in phosphorus limitation. J. Bioenerg. Biomembr. 2020, 52, 27-38. [CrossRef]

57. Shi, Y.; Liu, M.; Ding, W.; Liu, J. Novel insights into phosphorus deprivation-boosted lipid synthesis in the marine alga Nannochloropsis oceanica without compromising biomass production. J. Agric. Food Chem. 2020, 68, 11488-11502. [CrossRef]

58. Borowitzka, M.A. Limits to growth. In Wastewater Treatment with Algae, 1st ed.; Wong, Y.S., Tam, N.F.Y., Eds.; Springer: Berlin/Heidelberg, Germany, 1997; pp. 203-226.

59. Chen, J.; Wang, Y.; Benemann, J.R.; Zhang, X.; Hu, H.; Qin, S. Microalgal industry in China: Challenges and prospects. J. Appl. Phycol. 2016, 28, 715-725. [CrossRef]

60. Costa, J.A.V.; de Morais, M.G. An open pond system for microalgal cultivation. In Biofuels from Algae, 1st ed.; Pandey, A., Lee, D.J., Chisti, Y., Soccol, C.R., Eds.; Elsevier: Saint Luis, PHL, USA, 2013; pp. 1-22.

61. Sun, Z.; Liu, J.; Zhou, Z.G. Algae for biofuels: An emerging feedstock. In Handbook of Biofuels Production, 2nd ed.; Luque, R., Lin, C.S.K., Wilson, K., Clark, J., Eds.; Woodhead publishing: Cambridge, UK, 2016; pp. 673-698.

62. Khatoon, N.; Pal, R. Microalgae in biotechnological application: A commercial approach. In Plant Biology and Biotechnology; Bahadur, B., Venkat Rajam, M., Sahijram, L., Krishnmurhty, K.V., Eds.; Springer: New Delhi, India, 2015 ; Volume 2, pp. $22-47$. [CrossRef]

63. Arumugam, M.; Agarwal, A.; Arya, M.C.; Ahmed, Z. Influence of nitrogen sources on biomass productivity of microalgae Scenedesmus bijugatus. Bioresour. Technol. 2013, 131, 246-249. [CrossRef]

64. Kumar, R.R.; Rao, P.H.; Arumugam, M. Lipid extraction methods from microalgae: A comprehensive review. Front. Energy Res. 2015, 2, 61 .

65. James, I.; Yoon, L.W.; Chow, Y.H. Effect of phosphorus-limited nutrients on growth and glucose production from microalgae. In Proceedings of the International Engineering Research Conference, Subang Jaya, Malaysia, 3-4 July 2019; AIP Publishing: College Park, MD, USA, 2019; Volume 2137, p. 020005.

66. Ji, C.F.; Yu, X.J.; Chen, Z.A.; Xue, S.; Legrand, J.; Zhang, W. Effects of nutrient deprivation on biochemical compositions and photo-hydrogen production of Tetraselmis subcordiformis. Int. J. Hydrogen Energy. 2011, 36, 5817-5821. [CrossRef]

67. Lin, H.; Shavezipur, M.; Yousef, A.; Maleky, F. Prediction of growth of Pseudomonas fluorescens in milk during storage under fluctuating temperature. J. Dairy Sci. 2016, 99, 1-9. [CrossRef] [PubMed]

68. Přibyl, P.; Cepák, V.; Zachleder, V. Oil overproduction by means of microalgae. In Algal Biorefineries; Bajpal, R., Prokop, A., Zappi, M., Eds.; Springer: Dordrecht, The Netherlands, 2014; Volume 1, pp. 241-273.

69. FAO. Code of Conduct for Responsible Fisheries; Food and Agricultural Organization of the United Nations: Rome, Italy, 1996.

70. Zhu, L.D.; Li, Z.H.; Hiltunen, E. Strategies for lipid production improvement in microalgae as a biodiesel feedstock. Biomed. Res. Int. 2016, 8792548. [CrossRef]

71. Zachleder, V.; Brányiková, I. Starch overproduction by means of algae. In Algal Biorefineries; Bajpai, R., Prokop, A., Zappi, M., Eds.; Springer: Dordrecht, The Netherlands, 2014; Volume 1, pp. 217-240.

72. Vítová, M.; Bisová, K.; Kawano, S.; Zachleder, V. Accumulation of energy reserves in algae: From cell cycles to biotechnological applications. Biotechnol.Adv. 2015, 33, 1204-1218. [CrossRef]

73. Fernandes, B.; Teixeira, J.; Dragone, G.; Vicente, A.A.; Kawano, S.; Bišová, K.; Přibyl, P.; Zachleder, V.; Vítová, M. Relationship between starch and lipid accumulation induced by nutrient depletion and replenishment in the microalga Parachlorella kessleri. Bioresour. Technol. 2013, 144, 268-274. [CrossRef] [PubMed]

74. Tan, K.W.M.; Lee, Y.K. The dilemma for lipid productivity in green microalgae: Importance of substrate provision in improving oil yield without sacrificing growth. Biotechnol. Biofuels. 2016, 9, 255. [CrossRef] [PubMed]

75. Yoo, G.; Park, W.K.; Kim, C.W.; Choi, Y.E.; Yang, J.W. Direct lipid extraction from wet Chlamydomonas reinhardtii biomass using osmotic shock. Bioresour. Technol. 2012, 123, 717-722. [CrossRef] [PubMed]

76. King, J.W. Supercritical fluid technology for lipid extraction, fractionation and reactions. In Lipid Biotechnology, 1st ed.; Kuo, T.M., Gardner, H., Eds.; Marcel Dekker Inc.: New York, NY, USA, 2002; pp. 663-687.

77. Santana, A.; Jesus, S.; Larrayoz, A.; Filho, R.M. Supercritical carbon dioxide extraction of algal lipids for the biodiesel production. Procedia Eng. 2012, 42, 1755-1761. [CrossRef]

78. Patil, P.D.; Dandamudi, K.P.R.; Wang, J.; Deng, Q.; Deng, S. Extraction of bio-oils from algae with supercritical carbon dioxide and co-solvents. J. Supercrit. Fluids. 2018, 135, 60-68. [CrossRef] 
79. Folch, J.; Lees, M.; Stanley, G.H.S. A simple method for the isolation and purification of total lipids from animal tissues. J. Biol. Chem. 1957, 226, 497-509. [CrossRef]

80. Bligh, E.G.; Dyer, W.J. A rapid method of total lipid extraction and purification. Can. J. Biochem. Physiol. 1959, 37, 911-917. [CrossRef] [PubMed]

81. González-González, L.M.; Astals, S.; Pratt, S.; Jensen, P.D.; Schenk, P.M. Impact of osmotic shock pre-treatment on microalgae lipid extraction and subsequent methane production. Bioresour. Technol. Rep. 2019, 7, 100214. [CrossRef]

82. Milledge, J.J.; Nielsen, B.V.; Maneein, S.; Harvey, P.J. A brief review of anaerobic digestion of algae for bioenergy. Energies 2019, 12, 1166. [CrossRef]

83. Klassen, V.; Blifernez-Klassen, O.; Wibberg, D.; Winkler, A.; Kalinowski, J.; Posten, C.; Kruse, O. Highly efficient methane generation from untreated microalgae biomass. Biotechnol. Biofuels 2017, 10, 186. [CrossRef] [PubMed]

84. Tang, Y.; Zhang, Y.; Rosenberg, J.N.; Betenbaugh, M.J.; Wang, F. Optimization of one-step in situ transesterification method for accurate quantification of EPA in Nannochloropsis gaditana. Appl. Sci. 2016, 6, 343. [CrossRef]

85. Rafael, L.; Carol, S.K.L.; Karen, W.; James, C. Handbook of Biofuels Production, 2nd ed.; Woodhead publishing: Cambridge, UK, 2016; pp. 1-770.

86. Praveenkumar, R.; Shameera, K.; Mahalakshmi, G.; Akbarsha, M.A.; Thajuddin, N. Influence of nutrient deprivations on lipid accumulation in a dominant indigenous microalga Chlorella sp., BUM11008: Evaluation for biodiesel production. Biomass Bioenerg. 2012, 37, 60-66.

87. Prommuak, C.; Pavasant, P.; Quitain, A.T.; Goto, M.; Shotipruk, A. Microalgal lipid extraction and evaluation of single-step biodiesel production. Eng. J. 2012, 16, 157-166. [CrossRef]

88. Sasser, M. Identification of Bacteria by Gas Chromatography of Cellular Fatty Acids. MIDI; Technical Note \#101: Newark, DE, USA, 1990.

89. Glucksman, A.M.; Skipper, H.D.; Brigmon, R.L.; Santo Domingo, J.W. Use of the MIDI-FAME technique to characterize groundwater communities. J. Appl. Microbiol. 2000, 88, 711-719. [CrossRef] 